\title{
Paleopathological, Trichological and Paleoparasitological Analysis of Human Skeletal Remains from the Migration Period Cemetery Prague-Zličín
}

\author{
Lenka Vargováa , Ladislava Horáčkováa, Marcela Horákováb* ${ }^{*}$, Hana Eliášovác, Eva Myškovád, \\ Oleg Ditrich $^{\mathrm{d}}$ \\ aDivision of Medical Antropology, Department of Anatomy, Faculty of Medicine, Masaryk University, Kamenice 3, 625 00 Brno, Czech Republic \\ ${ }^{b}$ Labrys, o.p.s., Hloubětínská 16/11, 19800 Praha 9, Czech Republic \\ 'Institute of Criminalistics Prague, Bartolomějská 347/14, 11000 Praha, Staré Město, Czech Republic \\ ${ }^{d}$ University of South Bohemia, Faculty of Science, Department of Parasitology, Branišovská 1760, 37005 České Budějovice, Czech Republic
}

\section{ARTICLE INFO :}

\section{Article history:}

Received: $11^{\text {th }}$ December 2015

Accepted: $26^{\text {th }}$ October 2016

\section{Key words:}

Migration Period

Vinařice cultural group

paleopathology

internal frontal hyperostosis

biparietal thinning

calcaneonavicular coalition

trichology

paleoparasitology

aDNA

molecular methods

\begin{abstract}
$A B S T R A C T$
The study deals with the paleopathological analysis of human skeletal remains found in 173 Vinařicecultural-group graves at Prague-Zličín from the early stage of the Migration Period (5 ${ }^{\text {th }}$ century). Because the osteological collection was fragmentary, skeletal remains of only 113 individuals were analysed (26 men, 33 women, 19 children, and 6 adolescents; the sex of 29 adults remained unspecified). Paleopathological diagnoses were grounded in macroscopic and X-ray examinations. Most frequently, skeletal remains showed progressive degenerative processes such as spondylosis $(49.1 \%$, evaluated cases $n=53)$ and arthrosis $(37.7 \%$, evaluated cases $n=69)$. Traces of healed traumas were detected in $8.8 \%(n=113)$ of all the preserved individuals. Demonstrations of inflammatory symptoms were observed in $16.8 \%,(n=113)$ of the cases, out of which were two suspected cases of tuberculosis. Regarding neoplastic diseases, only two benign tumours (skull osteomas) were diagnosed ( $3.9 \%$, evaluated cases $n=51)$. Internal frontal hyperostosis, biparietal thinning, and calcaneonavicular coalition were detected only sporadically. Cribra orbitalia was detected in the eye sockets of $7.1 \%$ $(n=28)$ of the evaluated cases. Trichological analyses dealt with 203 samples, most of them were of recent or animal origin; only in four cases ancient human hair was found. To date the samples from graves No. 4, 11, 100-173 have been analysed and results of this analysis are presented in this study. Destruction of historical hair shafts was manifested by ragged and cracked cuticle scales, absence of cuticle scales, longitudinal loosened shafts and especially transversal fragmentation of hair shafts. Hair also showed marked damage owing to keratinophilic organisms. No human ectoparasites were found. Paleoparasitological analyses dealt with 30 samples from grave fillings; specifically from pelvic $(n=16)$, head $(n=1)$ and thoracic $(n=13)$ area. Despite the very sensitive molecular methods we employed, no signs of parasitological DNA were found.
\end{abstract}

\section{Introduction}

The analysed human skeletal remains, classified into the Vinařice cultural group of Germanic populations of the early stage of the Migration Period ( $5^{\text {th }}$ century) come from the Prague-Zličín area. The first findings about Vinařice graves were published in the $19^{\text {th }}$ century (Svoboda 1965). During the following periods, isolated graves as well as small family graveyards of ten to thirty graves were uncovered in various locations (Droberjar 2002); however, only fundamental

*Corresponding author. E-mail: horakova@labrys.cz archaeological methods were used to analyse the majority of them. No paleoanthropological nor health status research was performed.

In central Europe, the Prague-Zličín Vinařice burial ground with its 173 graves is the largest uncovered burial site which has survived from this slightly researched period. The burial site was excavated in the form of a rescue excavation due to a projected construction in the years 2005 to 2008 (for detailed information about the excavation see Vávra et al. 2009; 2012; Vávra 2016). In addition to archaeological studies (Vávra et al. 2009; 2012), basic anthropological research of the human skeletal remains also took place (sex, age, preservation, body stature, Víšková et al. 2012). Other 
work was by Kubálek and Malá (2011) but this focused only on a female face reconstruction of grave no. 78. These two studies are thus insufficient to provide an overall view of the health status of the Vinařice people.

Comparative materials, such as are available, are the similarly dated skeletal collections $\left(5^{\text {th }}\right.$ century AD) from Munich-Perlach (Zintl, von Heyking 2016) and Horb-Altheim (Obertová 2008), which are also precisely anthropologically evaluated. These collections are smaller than the PragueZličín population, but are better preserved and provide quite good data sets. Independently, a detailed dental remains and microwear analysis was undertaken on the Prague-Zličín skeletal material (Jarošová 2016), providing substantial information about caries intensity, dental losses, enamel hypoplasia or dietary habits.

Because of the fragmentary information concerning diseases of the Vinařice cultural group, this study is focused on a very detailed examination and medical description of each paleopathological finding of skeletal material. This approach is unique for our country and given time period. For this reason we also employed trichological and parasitological analyses that would help us to study the health status. There was no specific information concerning the occurrence of gastrointestinal or ectoparasites, so any information we might obtain would be a substantial contribution. The main goal of the trichological examination was to determine whether any historical human/animal hair occurred and, if so, to describe the structure of the human hair and perform a taxonomic determination of the animal hair. We also focused on the presence of human ectoparasites.

In this study we have aimed to answer the following main questions: What can we say about the health status of the Vinarice people? Can we observe some sex or age differences between male and female morbidity? Is it possible to find ancient human hairs in the grave fillings? Is it possible to recognise human ectoparasites e.g. head louse? Are the molecular methods able to capture DNA of intestinal parasites in the grave fillings?

\section{Materials}

\subsection{Palaeopathological analyses}

During archaeological excavations of the Prague-Zličín burial site, 173 graves (with 176 burials) were uncovered, revealing completely or partially decomposed skeletons. Thus, the osteological complex was mostly fragmentary, enabling the evaluation of the skeletal remains of only 113 individuals (26 men, 33 women, 19 children, and 6 adolescents; the sex of 29 adults could not be estimated). The paleopathological study resulted from the anthropological analysis was published in the work of Víšková (Víšková et al. 2012; Vávra et al. 2012, Table 1).

\subsection{Trichological analyses sampling}

Some organic material was macroscopically observed in the head parts of grave infillings in graves No. 4 and 11. These two samples of this material were directly taken for trichological analyses. All other samples / material for trichological analyses were obtained after grave infillings flotation (334 samples). Material from every infilling layer was sampled: there were therefore more samples than graves (336 trichological samples from a total of 173 graves).

\subsection{Parasitological analyses sampling}

Graves for parasitological analyses were selected at random, each sample being taken from a different grave. In total, 30 samples were taken, 16 samples from the pelvic area, 13 samples from thoracic area, and 1 sample from the head area.

For detailed information on which graves were sampled for analyses, please see the summary table included in this IANSA issue (Vávra 2016).

\section{Methods}

\subsection{Paleopathological methods}

The usual medical diagnostic and evaluating methods and approaches were used, such as anamnesis, unbiased examination, working diagnosis, differential diagnosis and final diagnosis.

However, due to the nature of the paleomaterial, the application of some of these methods was limited. Personal anamnesis was therefore replaced by the standard paleoanthropological analysis of skeletons using anthropometric and morphoscopic methods. This enabled the estimation of biological age and gender, of body physique (based on skeleton robustness), as well as the variability of measurements.

We searched for disease marks in a personal anamnesis / paleoanthropological analysis. We also used non-specific stress marks on bones, such as Harris lines (Horáčková et al. 2004), cribra orbitalia (Møller-Christensen et al.

Table 1. Basic demographic data of the Prague-Zličín population.

\begin{tabular}{|c|c|c|c|c|c|c|c|c|c|c|c|}
\hline \multirow{2}{*}{ Sex/age } & $0-0.5 \mathrm{yr}$ & $0.5-6$ yrs & $7-14$ yrs & 15-19 yrs & 20-30 yrs & $30-40$ yrs & $40-50$ yrs & $50-60$ yrs & \multirow{2}{*}{ Adults } & $60+y r s$ & \multirow{2}{*}{ Summ } \\
\hline & Infans I & Infans II & Infans III & Juvenis & Adultus I & Adultus II & Maturus I & $\overline{\text { Maturus II }}$ & & Senilis & \\
\hline Subadult & & 14 & 5 & 6 & & & & & & & 25 \\
\hline Male & & & & 3 & 1 & 3 & 9 & 7 & 3 & & 26 \\
\hline Female & & & 1 & 2 & 4 & 7 & 13 & 4 & 2 & & 33 \\
\hline Indeterminated & & & & & 8 & 8 & 3 & 5 & 5 & & 29 \\
\hline Summ & 0 & 14 & 6 & 11 & 13 & 18 & 25 & 16 & 10 & & 113 \\
\hline
\end{tabular}


1963; Hengen 1971; Horáčková et al. 2004), tooth enamel or dentin hypoplasia (Strouhal 2004). All these non-specific marks can inform about the changes occuring in bones after some diseases that could not be identified exactly.

We did not analyse familial diseases due to the anonymous character of the studied material; the buried population was therefore analysed as a whole.

The analyses started with standard paleoanthropological research followed by detailed macroscopic research. Based on that, we then evaluated if the discovered morphological changes in the bones represented some common variability deviations, or if they represented some disease. We described the exact position of all pathological nidi on the skeleton: their number, size, margins and general nature, and also photodocumented them.

We focused on the distribution of these changes as some of the diseases are characterized by unifocal nidi and some by numerous locations of lesions over the skeleton.

We evaluated the paleopathological findings mainly in accordance to the methodological criteria of Steinbock (1976), Ortner and Putschar (1985), Vyhnánek et al. (1998), Aufderheide and Rodríguez-Martín (1998), Ortner (2003) and Horáčková et al. (2004).

Bones were evaluated by naked eye, magnifying glass and also by microscope. In some cases where the finding was sufficiently typical, we have been able to determine the diagnosis after just a basic evaluation. In other cases, macroscopic evaluation was able to select a suspected case (i.e. to determine a working diagnosis) suitable for determination by other financially-more-demanding methods and thus determine a final diagnosis (i.e. differential diagnostics).

One such method was radiological examination, its use being necessary in cases of trauma, inflammation and so on. $\mathrm{X}$-Ray images were evaluated following the methodology of Vyhnánek et al. (1998).

Some pathological lesions were compared with similar contemporary medical findings (some of them in Smrčka et al. 2009) or with recent skeletal material (deposited in Pathologisch - Anatomisches Bundesmuseum in Wien) of known diagnosis determined by the most recent clinical methods.

\subsection{Trichological methods}

Hairs were separated from the macro-remains material under the stereomicroscope. Firstly, coarse impurities (especially minute pebbles) were removed from the samples stored in plastic test-tubes. Subsequently, impurities stuck on the surface of the selected samples were displaced using weak detergent solution; samples were then rinsed with distilled water and ethanol (Baumgartner, Hill 1993). Initial examination of hairs and other material was by stereomicroscope, macroscopic characteristics such as length and form being recorded. Selected material was also mounted in the medium of paraffin oil (refractive index 1.457). Specimens were examined using a compound light microscope Olympus BX 51 (transmitted light and polarized light) with magnification $200-400 x$. Microscopic photo documentation was taken with the use of a stereo microscope Olympus SZH 10.

Firstly the origin of material was determined, e.g. human or animal, animal fibres, plant fibres, artificial fibres, feathers or plant tissues (Teerink 2003; Appleyard 1978). Microscopic characteristics of human hair were documented: diameter; colour; presence; damage and pattern of cuticle; cortex characteristics - cellular texture; size and distribution of pigment granules; medulla pattern; characteristics of proximal part (e.g. root absent - form of the end; root present - determination of development stage - anagen, catagen, telogen, Ogler, Fox 1999); characteristics of distal tip; and hair features obtained through environmental conditions or by artificial treatments (e.g. structural damage due to taphonomic factors, insect bites, mould attacks, bleaching, dying...) (Chang et al. 2005; Brothwell 2005).

Mapping of the hair surface (present or absent cuticle scales, outer cuticle margins) and analyses of the surface impurities were realized by means of a scanning electron microscope. Hair samples were fixed on adhesive carbon targets and sputtered by gold in a SC500 device. Imaging documentation was taken using a scanning electron microscope Tescan Vega 5136XM in connection with an energy dispersive microanalyzer with characteristic radiation X-Link ISIS Series 300. Settings of the scanning electron microscope Tescan Vega 5136 XM were: accelerating voltage $20 \mathrm{kV}$; Probe Current (PC): 5-8; operating distance (WD): 10-25 mm; detector: BSED; heating: MIDDLE; Scan Mode RESOLUTION; Scan speed: 0-8; magnification 70$5000 \times$.

\subsection{Parasitological methods}

Determining the origin of intestinal parasites in archaeological material is often problematical. The only reliable connection to the host is the finding of the parasite directly in the human or animal remains. In this study soil samples from graves were worked on using highly sensitive methods, a combination of both microscopic and molecular methods. In the case of the paleoparasitological study we decided to combine classical parasitological methods (microscopy), methods for pollen analysis (chemical and mechanical maceration), and molecular analyses (DNA isolation, PCR) - every sample being elaborated by each method. This procedure was used in order to compare results originating from different sample-preparation methods and thus increase the probability of detecting a parasite.

Parasitological soil samples were rehydrated in a solution of $0.5 \%$ trisodium phosphate (Callen, Cameron 1960) and then treated with two techniques: 1, sedimentation - AMS III concentration technique; and 2, flotation-Sheather sugar solution. Moreover, samples were prepared as for pollen analysis (Faegri, Iversen 1989). These samples prepared with three different techniques, and another 24 samples from the pollen part of the research, were observed using the light microscope (Olympus BX 51) at magnification 200× and $400 \times$. 
The next step was the isolation of DNA and the following PCR techniques specific for Cryptosporidia, microsporidia, Trichuris sp. and Ascaris sp.

Nested PCR protocols were used to amplify the ITS region of the rRNA gene of E. bieneusi and Encephalitozoon (Buckholt et al. 2002; Didier et al. 1995; Katzwinkel- Wladarsch et al. 1996). A nested PCR protocol for Giardia described by Sulaiman et al. (2003) was used to amplify the TPI fragment. The amplification of a partial sequence of the SSU rRNA gene described by Jiang et al. (2005) was used for Cryptosporidium parasites. Single PCR amplification was carried out for amplification of the SSU rRNA gene of Trichuris (Oh et al. 2010) and for Ascaris sp. was used a primer set flanking the cytochrome $b$ fragment described by Loreille et al. (2001).

For the primary step of the nested PCR protocol, the PCR mixture contained $1 \times$ PCR buffer, $3 \mathrm{mM} \mathrm{MgCl}_{2}, 0.2$ $\mathrm{mM}$ each deoxynucleoside triphosphate (dNTP), 1 U Taq polymerase, bovine serum albumin (BSA) $(10 \mu \mathrm{g} / \mathrm{ml})$, and $200 \mathrm{nM}$ of each primer. For the secondary step of PCR, the PCR mixture was identical, except BSA was excluded. For every step of the nested PCR (standard procedure) for Cryptosporidium, Giardia and microsporidia, 35 cycles were run, each consisting of $94{ }^{\circ} \mathrm{C}$ for $45 \mathrm{sec}$, annealing temperature specific for each targeted genus, $72{ }^{\circ} \mathrm{C}$ for $60 \mathrm{~s}$. Initial incubation at $94{ }^{\circ} \mathrm{C}$ for $3 \mathrm{~min}$ and final extension at
$72{ }^{\circ} \mathrm{C}$ for $7 \mathrm{~min} / 10 \mathrm{~min}$ were included. Negative inhibition controls were included in each run. PCR products were visualized on a $1 \%$ agarose gel containing $0.2 \mathrm{~g} / \mathrm{ml}$ ethidium bromide, isolated from the gel with the use of QIAquick Gel Extraction Kit (Qiagen, Hilden, Germany) and directly sequenced on an ABI 3730XL sequence analyzer (Applied Biosystems, Foster City, California).

\section{Results}

\subsection{Paleopathology}

Joint diseases are among the most common findings on the skeletal remains of inhabitants from various historical periods. Most frequent are degenerative joint changes that may be localised on the spine (spondylosis and spondylarthrosis) and on large limb joints (arthrosis). In similar fashion, traces of a combination of destructive and productive processes were the most frequently discovered during the examination of the pathological changes of the Prague-Zličín human skeletal remains.

\subsubsection{Degenerative changes}

Only 53 skeletons were examined for spondylosis and spondylarthrosis because no vertebrae of the other individuals

Table 2. Occurrence of spondylosis. Explanation: $\mathrm{f}$ - female, $\mathrm{m}$ - male; J - juvenis, A I - adultus I (20-30 years), A II - adultus II (30-40 years), M I - maturus I (40-50 years), M II - matures II (50-60 years), S - senilis (more than 60 years); C - cervical vertebrae, T - thoracic vertebrae, L - lumbar vertebrae, $\mathrm{S}$ - sacral vertebrae.

\begin{tabular}{|c|c|c|c|c|}
\hline Grave No & Sex & Age category & Localization (vertebrae) & Observation \\
\hline $528 / 17$ & $\mathrm{f}$ & M I & $\mathrm{C}$ & erosion of surfaces \\
\hline $530 / 19$ & $\mathrm{f}$ & M I & $\mathrm{C}$ & erosion of surfaces, eburnation, osteophytes $4 \mathrm{~mm}$, \\
\hline $535 / 24$ & $\mathrm{f}$ & A II & $\mathrm{T}, \mathrm{L}$ & erosion of surfaces, Schmorl's nodes \\
\hline $529 / 25$ & $\mathrm{f}$ & M I & $\mathrm{S}$ & osteophytes up to $1 \mathrm{~mm}$ \\
\hline $543 / 33$ & $?$ & $\mathrm{~J}-\mathrm{A} \mathrm{I}$ & $\mathrm{C}$ & Schmorl's nodes \\
\hline $572 / 54$ & $\mathrm{f}$ & A II - M I & $\mathrm{C}$ & osteophytes up to $1 \mathrm{~mm}$ \\
\hline $590 / 62$ & $\mathrm{~m}$ & M I-M II & $\mathrm{C}$ & erosion of surfaces \\
\hline $591 / 63$ & $\mathrm{~m}$ & M I & $\mathrm{T}, \mathrm{L}, \mathrm{S}$ & erosion of surfaces, asymmetry, osteophytes $7 \mathrm{~mm}$ \\
\hline $721 / 71$ & $\mathrm{~m}$ & M I & $\mathrm{C}, \mathrm{T}, \mathrm{L}, \mathrm{S}$ & erosion of surfaces, osteophytes $2-5 \mathrm{~mm}$ \\
\hline $721 / 77$ & $\mathrm{~m}$ & M I & $\mathrm{C}, \mathrm{T}, \mathrm{L}, \mathrm{S}$ & erosion of surfaces, osteophytes $5 \mathrm{~mm}$, Schmorl's nodes \\
\hline $722 / 78$ & $\mathrm{f}$ & M I - M II & $\mathrm{C}, \mathrm{T}, \mathrm{L}, \mathrm{S}$ & erosion of surfaces, osteophytes $2,2 \mathrm{~mm}$, Schmorl's nodes \\
\hline $778 / 95$ & $\mathrm{f}$ & M I - M II & $\mathrm{L}$ & erosion of surfaces, osteophytes $5 \mathrm{~mm}$, Schmorl's nodes, eburnation \\
\hline $784 / 100$ & $?$ & A I & $\mathrm{C}$ & osteophytes up to $1 \mathrm{~mm}$ \\
\hline $798 / 110$ & $\mathrm{f}$ & M I & $\mathrm{C}, \mathrm{T}, \mathrm{L}$ & erosion of surfaces \\
\hline $818 / 121 \mathrm{a}$ & $\mathrm{f}$ & M I & $\mathrm{L}$ & osteophytes 3-4 mm \\
\hline $1505 / 127$ & $\mathrm{f}$ & A I & $\mathrm{L}$ & erosion of surfaces \\
\hline $1509 / 131$ & $\mathrm{~m}$ & M II & $\mathrm{L}$ & erosion of surfaces \\
\hline $1559 / 145$ & $\mathrm{~m}$ & M I - M II & $\mathrm{C}$ & osteophytes 2-3 mm, eburnation \\
\hline $1570 / 151$ & $\mathrm{f}$ & M I & $\mathrm{T}, \mathrm{L}$ & osteophytes 4-7 mm \\
\hline $1573 / 154$ & $\mathrm{~m}$ & A II - M I & $\mathrm{T}, \mathrm{L}$ & osteophytes 3-4 mm, Schmorl's nodes \\
\hline $1593 / 159$ & $?$ & A II & $\mathrm{C}$ & osteophytes up to $1 \mathrm{~mm}$ \\
\hline $1594 / 160$ & $\mathrm{f}$ & $\mathrm{M}$ II $-\mathrm{S}$ & $\mathrm{C}$ & osteophytes $4 \mathrm{~mm}$ \\
\hline $1595 / 161$ & $\mathrm{f}$ & A II - M I & $\mathrm{C}$ & osteophytes $9 \times 2 \mathrm{~mm}$, erosion of surfaces \\
\hline $1596 / 162$ & $\mathrm{f}$ & A II & $\mathrm{T}, \mathrm{L}$ & osteophytes 3-7 mm \\
\hline $1597 / 163$ & $\mathrm{f}$ & M I - M II & $\mathrm{L}, \mathrm{S}$ & $\begin{array}{l}\text { osteophytes up to } 1 \mathrm{~mm} \text {, Schmorl's node, L4 spondylolysis and prolaps } \\
\text { of disc }\end{array}$ \\
\hline $1598 / 164$ & $\mathrm{~m}$ & $\mathrm{M}$ II - S & $\mathrm{T}, \mathrm{L}$ & osteophytes $5 \mathrm{~mm}$ \\
\hline
\end{tabular}


have survived. Degenerative changes were detected in nearly half of these 56 skeletons ( 26 cases; $49.1 \%$; $=53$ ), as seen in Table 2. The modified scheme of Stloukal, Vyhnánek (1976) was used to identify the individual examples of spondylosis and spondylarthrosis. Based on the scheme, the findings were classified into three groups according to the character of the morphological changes. Nearly half of the cases revealed first-degree disabilities in the form of subtle bony edges encircling the articular surface areas and terminal surfaces of the bodies of vertebrae (12 cases; $46.2 \%$; $n=26$ ). This group also included bony projections (osteophytes) of a small size and linear depressions on the terminal surfaces of

Table 3: Occurrence of arthrosis. Explanation: $\mathrm{f}$ - female, $\mathrm{m}$ - male; J - juvenis, A I - adultus I ( $20-30$ years), A II - adultus II (30-40 years), M I - matures I (40-50 years), M II - matures II (50-60 years), $\mathrm{S}-$ senilis (more than 60 years).

\begin{tabular}{|c|c|c|c|c|c|}
\hline Grave No & Sex & Age & Localization & Articulatio & Observation \\
\hline $530 / 19$ & $\mathrm{f}$ & M I & ulna dx. & cubiti dx. & osteophytes $2 \mathrm{~mm}$ \\
\hline $529 / 25$ & f & M I & scapula sin. & humeri sin. & osteophytes up to $1 \mathrm{~mm}$ \\
\hline $572 / 54$ & $\mathrm{f}$ & A II - M I & mandibula & temporomandibularis & osteophytes $2 \mathrm{~mm}$, deformation of surface \\
\hline $574 / 56$ & $\mathrm{f}$ & A II & $\begin{array}{l}\text { clavicula sin. } \\
\text { scapula } \sin .\end{array}$ & $\begin{array}{l}\text { sternoclavicularis sin. } \\
\text { humeri sin. }\end{array}$ & erosion of surfaces \\
\hline $591 / 63$ & $\mathrm{~m}$ & M I & $\begin{array}{l}\text { sternum } \\
\text { humerus sin. } \\
\text { ulna } \mathrm{dx} \text {. } \\
\text { ossa scaphoidea } \\
\text { os coxae } \mathrm{dx} \text {. }\end{array}$ & $\begin{array}{l}\text { sternoclavicularis } \mathrm{dx} \text {. } \\
\text { humeri sin. } \\
\text { radioulnaris dist. } \mathrm{dx} \text {. } \\
\text { radiocarpea et intercarpalis } \\
\text { coxae dx. }\end{array}$ & $\begin{array}{l}\text { erosion of surfaces, eburnation, osteophytes } 1-4 \mathrm{~mm} \text {, myositis } \\
\text { ossificans, ossification of ligaments }\end{array}$ \\
\hline $594 / 65$ & $\mathrm{~m}$ & M I & ossa coxae & coxae dx. et $\sin$. & osteophytes up to $1 \mathrm{~mm}$ \\
\hline $599 / 67$ & $?$ & $\mathrm{~J}$ & humerus & humeri & osteophytes up to $1 \mathrm{~mm}$ \\
\hline $721 / 77$ & $\mathrm{~m}$ & M I & $\begin{array}{l}\text { clavicula sin. } \\
\text { scapula sin. } \\
\text { humerus sin, } \mathrm{dx} \text {. } \\
\text { os coxae }\end{array}$ & $\begin{array}{l}\text { sternoclavicular. sin. } \\
\text { acromioclavicular. sin. } \\
\text { humeri dx., sin. } \\
\text { coxae dx., sin. }\end{array}$ & $\begin{array}{l}\text { erosion of surfaces, osteophytes } 1-8 \mathrm{~mm} \text {, osteochondritis } \\
\text { dissecans, ossification }\end{array}$ \\
\hline $722 / 78$ & $\mathrm{f}$ & M I - M II & $\begin{array}{l}\text { clavicula dx. } \\
\text { ossa coxae }\end{array}$ & $\begin{array}{l}\text { sternoclavicular. } \mathrm{dx} . \\
\text { acromioclavicular. } \mathrm{dx} \text {. } \\
\text { coxae sin., } \mathrm{dx} .\end{array}$ & osteophytes up to $1 \mathrm{~mm}$ \\
\hline $778 / 95$ & $\mathrm{f}$ & M I - M II & $\begin{array}{l}\text { radius sin. } \\
\text { ossa coxae } \\
\text { talus dx. } \\
\text { calcaneus dx., sin. }\end{array}$ & $\begin{array}{l}\text { radiocarpalis } \sin . \\
\text { coxae } \mathrm{dx} ., \mathrm{sin} . \\
\text { talocruralis } \mathrm{dx} .\end{array}$ & erosion of surfaces, osteophytes up to $1 \mathrm{~mm}$, exostoses $5 \mathrm{~mm}$ \\
\hline $795 / 107$ & $\mathrm{~m}$ & M? & calcaneus $\mathrm{dx}$. & & exostosis $5 \mathrm{~mm}$ \\
\hline $798 / 110$ & $\mathrm{f}$ & M I & ossa coxae & sacroiliaca dx., sin. & erosion of surfaces \\
\hline $800 / 112$ & $\mathrm{~m}$ & M I - M II & $\begin{array}{l}\text { humerus dx. } \\
\text { os metacarp. I. dx. } \\
\text { os coxae sin. } \\
\text { os coxae dx. }\end{array}$ & $\begin{array}{l}\text { cubiti dx. } \\
\text { carpometacar. I. dx. } \\
\text { coxae sin. } \\
\text { sacroiliaca dx. }\end{array}$ & $\begin{array}{l}\text { erosion of surfaces, osteophytes up to } 1 \mathrm{~mm} \text {, osteochondritis } \\
\text { dissecans }\end{array}$ \\
\hline $800 / 113$ & $\mathrm{~m}$ & M I & $\begin{array}{l}\text { ossa coxae } \\
\text { femur dx., sin. } \\
\text { patella sin. } \\
\text { tibia sin. }\end{array}$ & $\begin{array}{l}\text { sacroiliaca dx., sin. } \\
\text { genus sin. }\end{array}$ & erosion of surfaces, osteophytes $4 \mathrm{~mm}$, myositis ossificans \\
\hline $807 / 119$ & $\mathrm{~m}$ & M I & patella sin. & genus sin. & \\
\hline $818 / 121 \mathrm{a}$ & $\mathrm{f}$ & M I & $\begin{array}{l}\text { mandibula } \\
\text { scapula sin. } \\
\text { tibia sin. }\end{array}$ & $\begin{array}{l}\text { temporomandibul. } \mathrm{dx} \text {. } \\
\text { acromioclavic. sin. } \\
\text { genus sin. }\end{array}$ & osteophytes $2-10 \mathrm{~mm}$, eburnation \\
\hline $1509 / 131$ & $\mathrm{~m}$ & M II & humerus dx. & cubiti dx. & osteophytes up to $1 \mathrm{~mm}$, osteochondritis dissecans \\
\hline $1544 / 132$ & $\mathrm{~m}$ & A II - M I & os coxae sin. & coxae sin. & osteophytes up to $1 \mathrm{~mm}$ \\
\hline $1555 / 142$ & $\mathrm{~m}$ & M I & $\begin{array}{l}\text { clavicula } \mathrm{dx} . \\
\text { scapula } \mathrm{dx} . \\
\text { humerus } \mathrm{dx} \text {. }\end{array}$ & $\begin{array}{l}\text { acromioclavic. } \mathrm{dx} \text {. } \\
\text { humeri } \mathrm{dx} \text {. }\end{array}$ & osteophytes up to $1 \mathrm{~mm}$ \\
\hline $1559 / 145$ & $\mathrm{~m}$ & M I - M II & os metacar. III dx. & metacarpophal. III dx. & osteophytes up to $1 \mathrm{~mm}$ \\
\hline $1569 / 150$ & $\mathrm{f}$ & M I & $\begin{array}{l}\text { mandibula } \\
\text { humerus dx. }\end{array}$ & $\begin{array}{l}\text { temporomandibul. } \mathrm{dx} \\
\text { cubiti } \mathrm{dx} \text {. }\end{array}$ & osteophytes up to $1 \mathrm{~mm}$ \\
\hline $1593 / 159$ & $?$ & A II & scapula dx. & humeri $\mathrm{dx}$. & osteophytes up to $1 \mathrm{~mm}$ \\
\hline $1594 / 160$ & $\mathrm{f}$ & $\mathrm{M} I I-\mathrm{S}$ & os coxae sin. & coxae sin. & osteophytes up to $1 \mathrm{~mm}$ \\
\hline $1595 / 161$ & $\mathrm{f}$ & A II - M I & os coxae dx. & coxae dx. & osteophytes up to $1 \mathrm{~mm}$ \\
\hline $1596 / 162$ & $\mathrm{f}$ & A II & $\begin{array}{l}\text { humerus } \mathrm{dx} \text {. } \\
\text { radius } \mathrm{dx} \text {. }\end{array}$ & cubiti dx. & osteophytes up to $1 \mathrm{~mm}$, osteochondritis dissecans \\
\hline $1598 / 164$ & $\mathrm{~m}$ & $\mathrm{M} \mathrm{II}-\mathrm{S}$ & $\begin{array}{l}\text { talus sin. } \\
\text { calcaneus sin., dx. }\end{array}$ & talocalcaneonavic. sin. & osteophytes up to $1 \mathrm{~mm}$, exostoses \\
\hline
\end{tabular}


vertebrae - Schmorl's nodes. The vertebrae with osteophytes exceeding $3 \mathrm{~mm}$, which projected above the spine surface, were described as a greater degree of spondylosis and spondylarthrosis and were detected in 9 skeletons ( 9 cases; $34.6 \% ; n=26)$. The most severe degree of spondylosis and spondylarthrosis revealed mirror-smooth patches on articular surfaces (eburnation) and deformations of vertebrae bodies and articular surfaces ( 5 cases; $19.2 \%$; $=26$ ). Block vertebrae formed by the merging of large osteophytes on neighbouring vertebrae were not detected.

We also met other problems during the interpretation. It was very difficult to determine the border between a normal and pathological state. The degenerative-productive process is usually seen as a natural manifestation of the aging of connective tissues and is characterized by a lower vescularization of the tissue itself, of cartilage and of bones, and by their lower regenerative ability. The rate of development of this process is even used as an auxiliary method to determine a biological age of life expectancy (Dobisíková 1999). A mild degree of arthrosis is usually considered as the usual finding in cases of individuals older than 40 years. Therefore, arthrosis can be marked as a disease only in cases where the pathological changes do not correspond to the respective age (Rejholec 1982).

When comparing the degree of spondylosis and the age of the affected individuals, it emerges that only 16 cases $(30.2 \% ; n=53)$ showed an actual disease while the remaining findings of degenerative changes corresponded to the usual wearing of the musculoskeletal system caused by age.

The detailed examination of the individuals showed that the most severely part affected was their lumbar spine, then the thoracic and cervical sections, and the least affected was the sacrum. An article by Vargová et al. (2014) provides a detailed description of the joint impairment.

In addition to the spinal column, other joints were also affected by degenerative changes (Table 3) that were detected in 26 adult skeletons $(37.7 \%$; $=69)$; however, only 9 cases $(13.0 \% ; n=69)$ showed actual disease. The remaining findings were accorded the normal signs of ageing because they had been observed on skeletal remains of individuals aged 40 and above and corresponded with a mild degree of arthrosis. Hip joints were most frequently affected, followed by shoulders, elbows, collarbone joints, knees, and jaws.

\subsubsection{Traumas}

Apart from joint diseases, traumas were the next most frequent paleopathological findings. Traces of healed injuries were detected in $7.9 \%(n=9 / 113)$ of cases. A defect detected on the cranial vault of a man over 50, excavated from grave 1509/131, is exceptionally interesting. An ovalshaped opening is visible on the left parietal bone, the front edge of which begins at the coronal suture, $26 \mathrm{~mm}$ to the left of the bregma (Figure 1). The rear edge of the lesion and the dorsal part of the medial edge have been damaged posthumously and so the precise dimensions of the defect cannot be determined (the maximum width is $12 \mathrm{~mm}$, the length is estimated to circa $24 \mathrm{~mm}$ ). The edges of the



Figure 1. The oval-shaped opening on the left parietal bone. The preserved parts of the two edges have been rounded and neatly smoothed during the reparation process (about 50-year-old male, grave No. 1509/131). Photo by Lumír Trenčanský.

opening ascend inside the skull on the medial side. The preserved parts of the two edges have been rounded and neatly smoothed during the reparation process. The external table of calvaria near the defect shows signs of a chronic inflammatory process which form an edging $9 \mathrm{~mm}$ wide (15 mm dorsally) on the lateral side. The internal table of calvaria cannot be fully analysed because of severe damage; however, small perforations near the groove for the left middle meningeal artery and the superior sagittal sulcus indicate an inflammation. Although no fissures have been found near the wound, the poor condition of the calvaria makes it impossible to rule them out. The nature of the injury infers a possible slash inflicted from the right. A defect on the left parietal bone and the inclined medial border of the wound might indicate an anthropogenic injury caused by a right-handed attacker. The absence of visible cracks suggests that the cutting weapon was very sharp and the slash required great effort. Based on the different thickness of the bone on the edges of the opening, it is likely that the sharp edge hit the cranial vault in a slanted fashion. After the injury, the wound was probably cleansed, mainly its lateral edge, and bone fragments removed. This is evidenced by the width of the cut.

Nonetheless, the lateral edge of the wound was highly damaged which thwarted any detection of traces of a trepanation tool. Yet, it is evident that the affected individual lived for a long while after having suffered this injury, as indicated by signs of the reparation process. The symptoms of inflammation in the cranial cavity give evidence of posttraumatic chronic meningitis which in this type of injury is the most frequent cause of death, besides brain contusion (Tesař 1968).

Traumatic changes on the forearm bones of the upper left arm of a 35 to 45-year-old man from grave 1573/154 also appear to have been the result of interpersonal violence. The left ulna shows traces of a well-healed oblique fracture in the distal one third of the shaft. The peripheral fragment shows 




Figure 2. A) The left ulna shows traces of a well-healed oblique fracture in the distal one third of the shaft. B) The X-ray examination disclosed an infraction of the shaft of the adjacent left radius, located proximally from the ulna fracture (35-45-year-old male, grave No. 1573/154). Photo by Lumír Trenčanský.

a slight ad axim dislocation in the medial direction. Medical professionals refer to this type of ulna fracture between the central and distal section of the diaphysis as a defensive fracture ("parry fracture") resulting from situations when an individual holds out his forearm to defend himself from a blow. The fracture is usually found on the left hand because most individuals use their left hands for defence and dominant right hands for attack (Vyhnánek et al. 1998; Horáčková 2004). In most cases, radial bones remain intact; however, in this case, an X-ray examination disclosed an infraction of the shaft of the adjacent left radius, located proximally from the ulna fracture (Figures 2A, B). Moreover, posttraumatic arthrosis complicated the injury which was attested by arthrotic changes (articular surface erosions) detected on the head of the ulna and a minor osteophyte on the styloid process of the ulna.

In contrast to the above-mentioned case, a comminuted fracture of the right radius detected on the skeleton of a man in his forties or fifties, found in grave 1613/175, is believed to be a casual injury. The fracture was localised between the proximal and central third of the shaft, was not dislocated, and healed well. Isolated radius fractures in this localisation are rather rare and their clinical findings are inconspicuous. They are caused either by the direct impact of a strong force on the bone, by a blunt tool in the case of the comminuted fracture, or indirectly, when falling on the upper limb (Pokorný et al. 2002).

The traumatic changes in the upper extremities found at Prague-Zličín also included an infraction of the proximal finger phalanx of a woman aged 35-45 discovered in grave $572 / 54$. The macroscopic examination showed the abnormal bend of the affected finger part; the X-ray image revealed a partial break of the bone on the verge of the central and distal thirds. The break line was apparent in the sagittal projection, running obliquely in a proximal-distal direction. It appears to have been a casual injury arising from everyday activity, because injuries of this kind are rather frequent even in today's population. The bending of the affected bone was caused by the antagonistic traction of the interosseous muscles on the proximal fragment and of the finger extensor on the distal fragment (Kubáček et al. 1982).

A healed fracture of the right tibia of a 50-year-old man from grave 1559/145 belonged to severe injuries detected on the lower extremities. The break line ran obliquely in the distal third of the diaphysis. The peripheral fragment was dislocated medially ad axim and proximally ad longitudinem (Figures 3A, B). Current medical practice shows that isolated oblique tibia fractures are usually the result of a



Figure 3. A) A healed fracture of the right tibia in the distal third of the diaphysis, signs of pyogenic osteomyelitis have been detected nearby. B) The X-ray image shows inaccurately bordered areas of shade alternating with brighter areas close to the break line, and the bone losing its homogenous structure (about 50-year-old male, grave No. 1559/145). Photo by Lumír Trenčanský. 




Figure 4. A) Left tibia with a process protruding from the middle of the diaphysis - may be myositis ossificans. B) X-ray image does not show the normal bone structure (30-40-year-old male, grave No. 501/2). Photo by Lumír Trenčanský.

direct external force in the form of angle bending (Pokorný et al. 2002). Very likely it was an open fracture because signs of pyogenic osteomyelitis have been detected nearby. The X-ray image shows inaccurately bordered areas of shade alternating with bright areas close to the break line, and the bone losing its homogenous structure.

Macroscopic examination revealed a knobbly surface on the medial area of the affected tibia and a fistula with an opening of $5 \mathrm{~mm}$ in diameter in the centre. The defect is surrounded by several small perforations indicating that the inflammation process reached its chronic stadium.

A traumatic origin is also assumed in the case of pathological changes to the left tibia of a 30 to 40-year-old man from grave 501/2. A lateral bony projection (length: $38 \mathrm{~mm}$, proximal width: $10 \mathrm{~mm}$, distal width: $12 \mathrm{~mm}$ ) with a chipped-off distal part protrudes from the middle of the diaphysis. Three or four tiny pinhead-size holes were found on the ventral and dorsal sides. From the viewpoint of differential diagnosis, they might be myositis ossificans of the flexor digitorum longus muscle tendon. However, the $\mathrm{X}$-ray image does not show a normal bone structure (Figures $4 \mathrm{~A}, \mathrm{~B})$. Thus a fibula fracture where the bone projection would be the residue of the subsequent adhesion of the two shank bones cannot be excluded. A more accurate diagnosis is prevented by the poor condition and incompleteness of the skeletal remains.

Impairments of the axial skeleton were detected in a 45-year-old man from grave 591/63. His second right rib



Figure 5. A) Second right rib evinced a slightly thinned spot on its ventral third bordered by a dorsomedial bone projection. B) The X-ray examination showed a transverse fracture which healed properly (about 45-year-old male, grave No. 591/63). Photo by Lumír Trenčanský.

evinced a slightly thinned spot on its ventral third bordered by a $3 \mathrm{~mm}$ long dorsomedial bone projection. The X-ray examination shows a transverse fracture (Figures 5A, B) which healed properly. In addition, a fifth lumbar vertebra with bilateral intra-articular spondylolysis, i.e. a separated vertebral arch, was discovered. The aperture ran nearly vertically between the upper and lower joint projections. At the place of the defect, the non-knitted areas of the vertebral arch were covered with compact bone that has only a slightly



Figure 6. Osteochondritis dissecans located on the ventromedial edge of the left femur head (20-24-year-old female, grave No. 1610/172 a). Photo by Lumír Trenčanský. 
bumpy surface and tiny perforations. The spondylolysis in this case could be an after-effect of the trauma, emerging simultaneously with the rib fracture, and resulting in polytrauma.

In most cases, the contusion of soft tissue on skeletal remains cannot be detected. Ossifications of affected structures are the only exceptions; for example, the partially ossified anterior tibiofibular ligament on the left fibula of a 40 to 50 -year-old woman from grave 798/110. The ossified part of the ligament is $11 \mathrm{~mm}$ wide at the base and $6 \mathrm{~mm}$ tall. The bone surface is covered with a thin layer of compact bone while spongy bone is found inside. Contusion of the lateral ankle region appears to be the most likely cause of the ligament ossification.

A shallow depression of $7 \times 4 \mathrm{~mm}$ detected on the ventromedial edge of the articular head by the anatomical neck of the left femur of a 20 to 24-year-old woman from grave 1610/172a gives evidence of contusion of the left hip joint and partial avulsion of the articular cartilage, which is referred to as osteochondritis dissecans (Figure 6).

\subsubsection{Inflammations}

Nearly every larger skeletal collection shows traces of subacute or chronic inflammation. Inflammatory changes have been found on 19 human skeletal remains of PragueZličín (16.8\%; n=113). Cranial bones were most frequently affected by infections that spread from the oral cavity and the upper respiratory tract. Typical examples are signs of chronic parodontitis on the mandibles of four individuals in their forties or fifties, including three women (graves 722/78, 1555/142, and 1612/174) and one man (grave 721/77). Symptoms of chronic parodontitis were rounded smooth small bumps or bone edgings with very fine perforations around dental alveoli outside and inside the mandibles. In all these cases the occurrence of parodontitis was connected with the overall bad condition of the individual's teeth, which was caused either by the accumulation of profuse amounts



Figure 7. A fragment of the left maxilla with circular opening opened into the maxillary sinus. Newly-formed bone tissue as a result of chronic sinusitis (40-50-year-old female, grave No. 530/19). Photo by Lumír Trenčanský. of dental calculus or by cavities as remnants of periapical granulomas and cysts at the roots of the teeth.

The suppurative nidi of infection at the dental roots spread the inflammation to the parodontal tissue and paranasal sinuses. The left maxilla of a woman aged 40-50 found in grave 530/19 provides further evidence. A circular opening of $3 \mathrm{~mm}$ in diameter emerged at the buccal root of the second molar, which opened into the maxillary sinus (Figure 7). The edges of the defect have been smoothed during the reparation process. A newly-formed bone tissue of irregular shape appears on the medial area of the left maxillary sinus, apparently as a result of chronic sinusitis. Similar chronic inflammation of the maxillary sinus, though remarkably smaller, was observed on the upper left maxilla of a 35 to 45 -year-old woman from grave 572/54. In this case, the maxillary sinus was opened after a tooth extraction and infection spread inside the bone. An opening with smoothed edges was found at the place of the closed dental alveolus of the second molar. Inflammatory changes are evident both inside and outside the maxillary sinus.

Furthermore, temporal bones of three skulls of the Zličín skeletal collection were affected. There were traces of chronic inflammation of the middle ear (otitis media) where infection usually spreads from the nasopharynx via the auditory tube. A disrupted dorsal edge of the tympanic part was detected on the right temporal bone of a 45 to 55-yearold individual from grave 1609/171. The perforation is of an irregular shape; the edges having been smoothed over during the reparation process (Figure 8). Differential diagnosis suggested an innate dehiscence of the tympanic plate. The presence of inflammatory changes on the tympanic groove in the form of tiny bumps was the main criterion to diagnose otitis media. Other traces of middle ear infection were found



Figure 8. The presence of inflammatory changes on tympanic groove of the right temporal bone in the form of tiny bumps - a sign of chronic otitis media (45-55-year-old adult individual, grave No. 1609/171). Photo by Lumír Trenčanský. 




Figure 9. The left mastoid process with an opening on the outside leading to the mastoid cellulae. The edges of the opening have been smoothed during the reparation process - a sign of chronic mastoiditis (45-50-yearold male, grave No. 1555/142). Photo by Lumír Trenčanský.

on the skeleton of a 50 to 60 -year-old man in grave 522/10. Three irregularly-shaped perforations are visible on the anterior surface of the petrous portion of the left temporal bone. A thin, irregular layer of newly-formed bone mass of $15 \times 7 \mathrm{~mm}$ was found near their lateral edges. A similar infection was observed on the skeleton of a woman aged $30-40$ from grave 535/24. A number of irregularly-shaped openings appear on the anterior surface of the petrous portion of the right temporal bone; however, edges of only two of them, located by the sinus petrosus superior groove, have been smoothed over during the reparation process. As a result, it is impossible to clearly differentiate whether the majority of these openings perforating the tympanic cavity emerged posthumously and belong to taphonomic changes.

Mastoiditis was another health problem diagnosed on the skulls of the Zličín skeletons. Most often, mastoiditis results from otitis media complications when infection passes from the tympanic cavity in the mastoid cells, which may result in their coalescence as a consequence of osteoclastic destruction (Klozar et al. 2005). The finding on the skull of a 45 to 50-year-old man from grave 1555/142 corresponds to this diagnosis. The left mastoid process features an opening of $8 \times 5 \mathrm{~mm}$ on the outside leading to a cavity $3-4 \mathrm{~mm}$ deep. The edges of the opening have been smoothed over during the reparation process; the base of the defect is porous
(Figure 9). Suppuration leaked through this perforation to the skull surface, where it most likely resulted in retroauricular infiltration of soft tissues.

The finding of a subperiosteal abscess in the nuchal region on the occipital bone of a woman over 45 excavated from grave 529/25 indicates the more serious complication of mastoiditis. A circular lythical defect with smooth edges has been detected on the external surface of the squama of the occipital bone, about $47 \mathrm{~mm}$ below the lambda. The lesion penetrates all the way to the diploe, the edges being undermined, and the base $(12 \times 11 \mathrm{~mm})$ is partially smoothed over (Figure 10A). A groove about $10 \mathrm{~mm}$ long continues towards the lambda. A round opening on the dorsal surface of the right mastoid process, which leads to a cavity of



Figure 10. A) Traces of a subperiosteal abscess in the nuchal region on the occipital bone as a serious complication of mastoiditis. B) A lythic defect on the dorsal surface of the right mastoid process as a sign of chronic mastoiditis (about 45-year-old female, grave No. 529/25). Photo by Lumír Trenčanský. 
$9 \mathrm{~mm}$ in diameter inside the projection, gives evidence of the individual suffering from mastoiditis. The base of the lythical defect is smoothed; the edges of the opening bear signs of the reparation process (Figure 10B). The fact that in this case, together with a subperiosteal abscess, a more serious complication of mastoiditis could have occurred, means that intracranial infection cannot be ruled out. The sulci arteriosi arteriae meningeae mediae on the left are significantly wider than those on the right, and many small perforations are seen. To a certain extent the clinical picture resembles the manifestation of posttraumatic meningitis as described on the cut on the skeleton from grave 1509/131.

Inflammatory changes on upper extremities have been observed in two cases. The first one was the left radius of a 50-year-old woman from grave 778/95 where a fine accumulation of newly-formed bone tissue, about $50 \mathrm{~mm}$ in diameter, was found on the dorsal part of the distal end. The bone surface was coarsened with perforations up to $1 \mathrm{~mm}$ in diameter. The inflammatory nidus is localised under the tendons of the extensors that run below the extensor retinaculum. It is possible that the inflammation of the adjacent tendons and ligament structures occurred primarily and the aseptic irritation inflammation of the bone developed secondarily. Inflammatory changes on the proximal end of the left ulna of the 45 to 50-year-old man from grave 807/119 might be the result of a similar aetiology; a coarsened porous surface was observed on the radial notch of the ulna, the coronoid process, and on a fragment of the olecranon of the ulna.

The skeletal remains of the lower extremities revealed inflammatory processes on the right pelvic bone of a man over 55 from grave 1598/164, where the inflammation damaged the cranial edge of the acetabulum. The surface is bumpy and shows tiny perforations. The approximate lesion size is $28 \times 8 \mathrm{~mm}$; severe damage to the pelvic bone hinders the determination of more precise dimensions. The affected joint also shows signs of arthrosis - the dorsal edge of the acetabulum shows an osteophyte edge up to $5 \mathrm{~mm}$ high. The most significant traces of inflammation of the lower extremities were detected on the shinbones of a 45 to 50-yearold man from grave $612 / 79$. Nearly the entire diaphysis of the left tibia was affected. The surface of the bone is uneven with a lot of tiny perforations and irregular accumulations of the newly-formed bone tissue. Analogous changes have also fully damaged the left fibula diaphysis. In this case, chronic osteomyelitis was diagnosed as affecting the compact and spongy bones. The clinical picture is very much reminiscent of syphilitic osteomyelitis; however, this diagnosis should be excluded because of the date of the skeletal remains. The fragmentary condition of the examined skeleton did not facilitate a more detailed differential diagnosis of the pathological condition. The diagnoses of further occurrences of inflammation were difficult; for example, that on the right tibia of a 40 -year-old man from grave 797/109, where newly-formed bone tissue accumulated on the lateral side of the tibial tuberosity. Nevertheless, the scope of periostitis cannot be precisely determined because of the damage to the proximal end of the bone (the size of the lesion is estimated to be $43 \times 20 \mathrm{~mm}$ ). Another similar finding was that on the skeleton of a 45 to 50-year-old man from grave No. 801/113 where periostitic nidi were detected on the distal third of both tibias, on the medial surface and anterior border. A lesion of $32 \times 17 \mathrm{~mm}$ on the left side projects above the bone surface; the inflammatory nidus is damaged on the right so its size could only be estimated at about $68 \times 25 \mathrm{~mm}$. During the differential diagnosis determination we also took ossificated subperiosteal hematomas resulting from injuries or scurvy into consideration for their similarity to both the abovementioned cases.

In addition to non-specific inflammation, two skeletons of Prague-Zličín showed suspected cases of tuberculosis. In the first case, pathological changes on the spine of a woman aged 45-55 from grave 722/78 were detected, which could be diagnosed as Pott's disease. In addition to the signs of an advanced stage of spondylosis, traces of compression fracture were observed on the second lumbar vertebra. The body of the affected vertebra is wedge-shaped and lowered on the right by the ventral perimeter where it reaches only $10 \mathrm{~mm}$ while the dorsal height is $23 \mathrm{~mm}$. An osteophyte $11 \mathrm{~mm}$ high and about $23 \mathrm{~mm}$ wide can be seen at the maximum reduction. The superior terminal facet is inclined obliquely while the inferior terminal facet has remained intact, being oriented in the transversal plane. The collapse of the vertebra might be indicated by caseous necrosis of the tuberculosis nidus inside the body. Subsequently, the necrotic mass coursed down along the psoas major muscle into the pelvis resulting in a psoatic abscess. This assumption is further supported by a region of newly-formed bone tissue on the pelvic surface of the sacrum at the level of S2 (circa $8 \mathrm{~mm}$ in diameter). A circular depression of about $15 \mathrm{~mm}$ in diameter found on the internal surface of the wing of ilium, medially from the right anterior inferior iliac spina, may also be related to the abscess in the pelvis. It has a smooth base covered with a normal compact bone. The depression might have been caused by the pressure of a hypertrophic regional inguinal lymphatic node. However, differential diagnosis requires taking into account a possible atypical surface starting at the rectus femoris muscle.

The question remains whether changes on the ribs of this woman are also associated with tuberculosis, because they do not show any signs of a typical chronic inflammatory process. The cranial surface of the first left rib reveals a striking bone structure covered with a thin layer of compact bone (19 $\mathrm{mm}$ long, $12 \mathrm{~mm}$ wide, and $9 \mathrm{~mm}$ high). Furthermore, fragments of the dorsal third of two cranial ribs on the right side are knitted in the area of their costal angles. A fragment of the caudal rib shows a bone protrusion on the cranial edge which is $11 \mathrm{~mm}$ long and $5 \mathrm{~mm}$ high. Polytraumas must also be considered in differential diagnosis; therefore, partial ossification of intercostal muscles or membranes may have occurred.

The skeleton of a five-year-old child from grave 1556/143 showed obvious traces of pleuritis (most likely tuberculous). One of the left caudal ribs revealed a fine accumulation of 

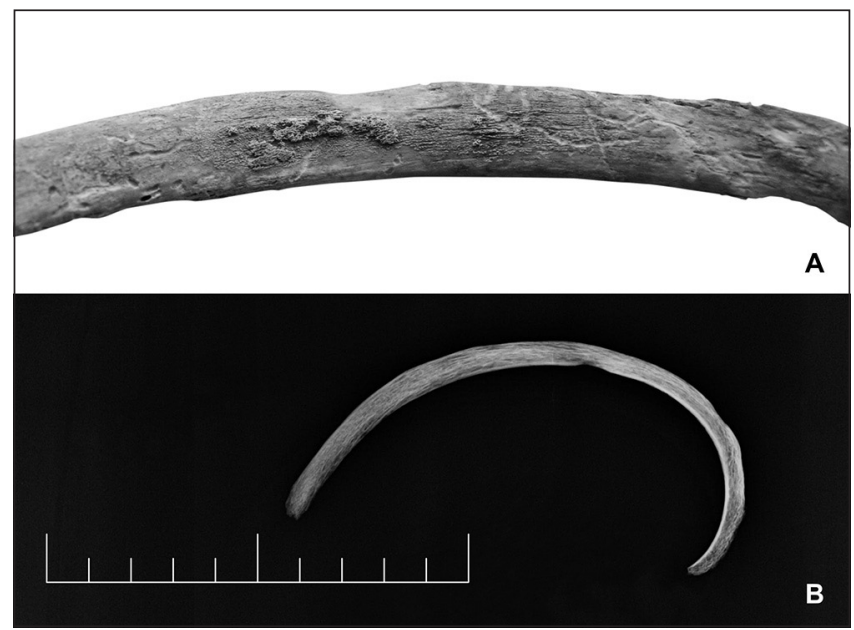

Figure 11. A) One of the left caudal ribs with a fine accumulation of newly-formed bone tissue. B) X-ray image exposed a blurred bone contour and damaged homogeneity of bone tissue (5-year-old child, grave No. 1556/143). Photo by Lumír Trenčanský.

newly-formed bone tissue (approximately $13 \times 4 \mathrm{~mm}$ ). The surface of the bone is coarsened and slightly porous. An $\mathrm{X}$-ray image exposed a blurred bone contour and damaged homogeneity of the bone tissue (Figures 11A, B). The longlasting chronic disease associated with a metabolic disorder is further evidenced by cribra orbitalia of the first degree on the upper margin of the eye sockets. In this case, periostitis as a consequence of chronic pleuritis can be confirmed.

\subsubsection{Tumors}

The paleopathological analysis of human skeletal remains of Prague-Zličín showed only benign bone tumours (osteomata) localised on two skulls $(3.9 \% ; n=51)$; in both cases on the right part of the frontal sinus. The diagnosis of osteomata was determined from the macroscopic examination according to their typical visual aspect. The tumour of a 35 to 45 -year-old woman from grave 574/56 was ball-shaped, about $10 \mathrm{~mm}$ in diameter, and had a smooth surface. A man aged 45-50 from grave $807 / 119$ had a conical-shaped osteoma with the base about $4 \mathrm{~mm}$ wide and $3 \mathrm{~mm}$ high. Both the osteomata had a normal bone structure; their surfaces were covered with a layer of compact bone, with spongy bone inside.

\subsubsection{Other osteopathies}

The pathological changes on the skull of the 45 to 50 -yearold woman from grave 530/19 can be regarded as endocrinal osteopathy. The interior surface of the left squama of the frontal bone revealed an uneven surface of the inner table with several rounded bumps separated by shallow depressions. The diploe is partially exposed on one of the bumps. Only an indication of similar changes is found on the right side of the frontal bone squama. Most probably, it is the beginning of a frontal internal hyperostosis. However, in this case, a traumatic origin for the lesion (for example, a subperiosteal hematoma) cannot be ruled out because one of the grooves, conditioned by a branch of the meningeal medial artery, is abnormally wide and several small perforations run along the groove for the superior sagittal sinus reaching to the internal occipital protuberantia of the occipital bone.

Manifestations of innate skeleton defects are classified among rare paleopathological findings. The Zličín osteological collection includes the case of the thinned parietal bone which was observed on the 40 to 50 -year-old woman from grave 798/110. The severely-damaged fragment of the calvaria revealed a round shallow depression (circa $30 \times 30 \mathrm{~mm}$ ) on the right parietal bone. It was impossible to assess the left side because the bone had deteriorated posthumously. Assumingly, it was a case of biparietal thinning.

\subsubsection{Cribra orbitalia}

Only two cases from the analysed skeletal collection $(7.1 \%$; $\mathrm{n}=28$; grave $1509 / 131$, grave $1556 / 143$ ) showed porotic changes on the upper part of orbits referred to as cribra



Figure 12. A) Coalition of tarsal bones on the left foot. B) X-ray shows a round protrusion of the calcaneus with the contact surface of the navicular bone, referred to as "Anteater Nose Sign" (45-50-year-old female, grave No. 530/19). Photo by Lumír Trenčanský. 
orbitalia, usura orbitae (Møller-Christensen et al. 1963), or hyperostosis spongiosa orbitae (Hengen 1971). The majority of paleopathologists regard cribra orbitalia as a manifestation of anaemia (e.g. Moseley 1963) or a nonspecific symptom of long-term stress.

\subsubsection{Tarsal coalition}

The coalition of tarsal bones on the left foot of the 45 to 50 -year-old woman from grave 530/19 can be included in innate diseases (Figure 12A). In this case, the anterior talar articular surface on the severely damaged left heel bone is missing, and the dorsomedial side of the articular surface of the cuboid features a contact surface to meet with a similar surface on the navicular bone (about $21 \mathrm{~mm}$ long and $8 \mathrm{~mm}$ wide). The base of the latter surface is covered with the compact bone with many small openings reaching into the spongy bone. The articular surface of the cuboid is narrower (c. $19 \mathrm{~mm}$ ) and slightly medially inclined. The abnormal contact surface on the navicular bone is $21 \times 8 \mathrm{~mm}$ and its surface corresponds to the contact surface on the heel bone. The left talus bone has a normal size but the perimeter of the articular head was damaged posthumously, so the scope and position of the navicular articular surface of the talus cannot be determined accurately. When placing these three bones into their correct anatomical positions, it appears that the talus bone head is slightly medially inclined whereas the navicular bone is shifted laterally towards the calcaneus. Some contact occurred between the navicular bone and calcaneus, probably as a result of synchondrosis or syndesmosis. Differential diagnosis took into account the criteria which Case and Burnett (2012) set for tarsal coalition determination. They include the typical localisation of the lesion, characteristic change of shape, and the corresponding contact surfaces on the neighbouring tarsal bones; the affected foot showed all these symptoms. A lateral X-ray projection (Figure 12B) exposed a round protrusion with a contact surface of the navicular bone which radiologists refer to as "Anteater Nose Sign" (Chapman 2007). Based on these findings, the traumatic origin (fracture, as well as osteochondritis dissecans) and arthrosis could be excluded. Since no other signs of developmental defects were detected on the analysed skeleton, the tarsal coalition in this case was apparently neither a part of Apert syndrome, NievergeltPearlman syndrome, nor PFFD (proximal femoral focal deficiency).

\subsection{Trichology}

Samples included human hair, animal hair, animal, plant and artificial fibres, fragments of feathers and plant tissues. In the microscopical preparations fibres highly predominated over hair - tufts of fibres occurred frequently. Head hair predominated in the samples, somatic hair occurring sporadically. The head hair is most likely recent. Damaged hair was compared with referential historical material. Some samples of hair were exposed to a significantly longer influence of environmental factors, but almost no examined hairs were historic. Also, no human ectoparasites were found.

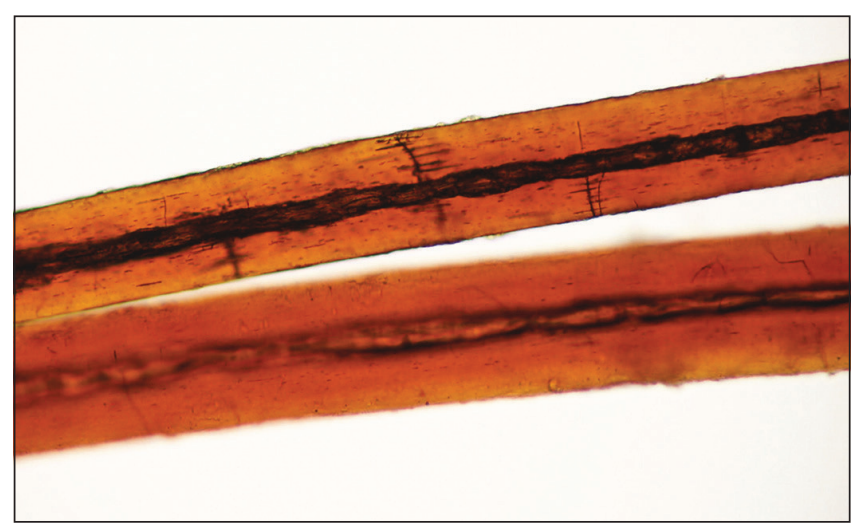

Figure 13. Human hair. Light brown shaft, black medullary canal filled by air. Photo by Tomáš Kmječ.

The exception is the grave sample 519/11 (juvenile individual). Hair fragments separated from soil reached to a length of 5-55 mm, with a maximum width of shafts $65-$ $105 \mu \mathrm{m}$. Hair fragments colouring in the transmitted light of the optical microscope were middle brown, sporadically light brown or dark brown, and always with a rutile tint caused by taphonomic changes in the melanin structure (Figure 13). Clumps of pigmental granules were visible here and there in the cortex; however, in most of the cases the origin of the pigment distribution was impossible to evaluate.

The medullary canal was either missing or was present in a discontinuous or continuous form. The preserved structure of the medulla was discernible only here and there. The original basal ends (roots) were not preserved in the surveyed samples. Proximal and distal ends were even (transversally) broken, frayed or irregular abraded.

The destruction of hair shafts was manifested by the ragged and cracked cuticle scales, absence of cuticle scales,



Figure 14: Human hair. Tunnels caused by keratinophilic organisms, air filled medullary canal. Photo by Tomáš Kmječ.



Figure 15. Human hair. Loosened shaft. Photo by Tomáš Kmječ. 



Figure 16. A) Human hair. Transversal hair shaft split, medulla in the centre of the hair. B) Human hair. Transversal hair shaft split (SEM). Photo by Tomáš Kmječ.



Figure 17. Human hair. Stuck deposits of inorganic material on the hair (SEM). Photo by Tomáš Kmječ.

longitudinal loosened shafts and especially transversal fragmentation of hair shafts. Hair also showed marked damage owing to keratinophilic organisms having created transversal and longitudinal tunnels (Figures 14, 15).

In the pictures from the electron microscope there were visible cuticle scales, damaged shafts and stuck deposits of inorganic material native to the surrounding spoil that partly caused some incrustation of hair shafts (Figures 16A, $B$, 17). An analysis of inorganic material proved the presence predominantly of aluminium and silicon (probably aluminosilicate) (Figures 18, 19).

Animal hairs were represented by guard hair and underhair in the samples. The medullary pattern, pigment in the cortex and especially the characteristic root shape determined dog guard hair. Underhair is not capable of exact taxonomic determination due to an insufficient amount of identification features.

Fibres were represented by sheep wool, cotton (twisted ribbon) and a great deal of artificial fibres (e.g. blue, red, light green, dark blue, yellow, etc.). These modern fragments come from the long period of excavation.

\subsection{Parasitology}

Despite the fact that we have used several different sample preparation methods to increase the probability of parasite detection, both microscopic and molecular analyses were negative for the presence of parasites. In several samples only pollen seeds were visible.

\section{Discussion}

The occurrence of osteophytic edges or bill-shaped osteophyts encircling articular surfaces, Schmorl's nodes on terminal surfaces of vertebral bodies, traces of osteochondritis dissecans, geodes in subchondral bones, eburnation of articular surfaces, or their significant deformations, were the main criteria to diagnose the degenerative changes on the human skeletal remains from Prague-Zličín (Steinbock 1976; Aufderheide, Rodríguez-Martín 1998; Ortner 2003). However, the interpretation of the results for these types of joint diseases has been rather questionable. The origin of the degenerative process is influenced by a lot of factors: innate genetic predispositions; age; sex; weight; nutrition; physical load on the musculoskeletal system; natural conditions; and overall health condition (Weiss, Jurmain 2007). The progression of degenerative changes in elderly individuals is a sign of the natural ageing of connective tissues (Dobisíková 1999). Therefore, as evidence the only true findings of this disease are such conditions where the detected pathological changes do not correspond to the relevant age category (Rejholec 1982). The chronic impairment of joints, however, does not allow an accurate borderline between standard and pathological changes to be determined (Ortner, Putschar 1985). In the case of individuals under forty, mild impairments of joints have been regarded as pathological while only a more serious degree of degenerative change have been regarded as a disease of the elderly during the skeletal remains analysis. Nevertheless, we are aware of a certain inaccuracy in the determination of final diagnoses because the current medical practice shows that the overall clinical picture (movement disorders, painfulness, etc.) does not always correspond to the degree of the manifested 
Figure 18. Composition of crust. Photo by Tomáš Kmječ.



Figure 19. Composition of the crust on the hair surface and composition of the soil (relative to the same volume of silicon). Photo by Tomáš Kmječ.



morphological changes - the latter being, of course, the only possible criteria of evaluation in paleopathological studies. The value of the paleopathological analysis of the osteological findings from Prague-Zličín was significantly limited by the considerably damaged state of the human skeletal remains, as stated by Víšková et al. (2012). For this reason, no statistical methods, such as those recommended by Nikita et al. (2013), could be used to assess the degenerative changes. The accurate prevalence and distribution of spondylosis and arthrosis, as, for example, that recorded in the study of Waldron (1991), could not be determined here in the case of this analysed population sample. Because of the small number of bones that could be evaluated, the degenerative changes were not used as a physical load indicator - as, for example, carried out by Jurmain (1977; 1991), Beňuš, Masnicová (2001), and Woo, Sciulli (2013). To evaluate this type of finding, a generally-recognised uniform way of classification has not yet been introduced in paleopathology; therefore, it is difficult to compare the study results with other human skeletal collections in central Europe, e.g. those of the Neolithic era (Crubézy et al. 2002), Slavic burial sites (Stloukal, Vyhnánek 1976; Kalová 2012), and modern cemeteries (Vargová, Horáčková 2005; Vargová et al. 2013). Despite all these difficulties, the analysis of human skeletal remains from Prague-Zličín may contribute to diachronic development of arthrosis and spondylosis in historical European populations.

Furthermore, spondylolysis is commonly detected in human skeletal collections. It is a unilateral or bilateral aperture-shaped interruption of the vertebral arch, most frequently between the upper and lower articular processes. The frequency of occurrence of spondylolysis in a population is estimated to be at 4-8\% (Aufdeheide, RodríguezMartín 1998). Two such cases were detected on the human skeletal remains from Prague-Zličín (graves 1597/163 and $591 / 63)$ which equals $3.7 \%(n=53$ individuals). This value corresponds with the existing findings on the frequency of spondylolysis in the European population and approximates to the prevalent value of $4.8 \%$, as Fibiger, Knüsel (2005) described on a skeletal collection from the $5^{\text {th }}-6^{\text {th }}$ centuries in Eccles, England. Nathan (1959) regards the range of values of spondylolysis occurrence in various populations to be the result of different predisposition factors, which are genetically coded, and whose degree of manifestation depends on local conditions. Žižka (1994) claims that the defects of vertebral arches may be one of the symptoms of 
genetically-determined syndromes, such as chondrodysplasia punctata, Gorlin-Goltz syndrome, Klippel-Feil syndrome, and others. In addition to congenital developmental disorders, innate predispositions for the activation of spondylolysis by external factors must be taken into account. Such importance is further supported by the gradually increasing incidence of this disorder in children and adolescents (Fredrickson et al. 1984; Tsirikos, Garrido 2010); an increase has also been detected in adults (Kalichman et al. 2009). In most cases, acquired spondylolysis is regarded as a fatigue fracture caused by repeatedly overloading the spine (more accurately pseudoarthrosis) which would logically correspond to its occurrence in the functionally-strained part of the spine. A direct one-time traumatic event rarely occurs (Wiltse et al. 1975). The human skeletal remains from PragueZličín included a female skeleton (grave 1597/163) where spondylolysis was accompanied by a prolapse of an intervertebral disc, which made it impossible to differentiate between congenital and traumatic origin. A rib fracture was detected on a male skeleton (grave 591/63) in addition to spondylolysis); therefore polytrauma was contemplated with respect to aetiology.

A healed cut-wound on a male skull from grave 1509/131 was one of the most severe injuries within the analysed collection. It was a typical anthropogenic injury inflicted by a right-handed attacker. Based on the angle from which the cutting weapon struck the individual, one could estimate that the attacker was of similar height to that of the victim. All attributes of the slash wound that could be evaluated, as drawn up by Lewis (2008), were taken into account when determining the type of weapon. A great force was used for the slash which was performed with a heavy and sharp tool, perhaps a sword or an axe. However, no cutting weapons were discovered at the Prague-Zličín burial site (Vávra et al. 2009) and so the type of tool can only be speculated on. Similarly, the method of medical treatment of the injury was ambiguous, because the lateral edge of the defect was severely damaged. Assuming that the cutting weapon struck at an oblique angle, its edge should have been dull or lobeshaped. But the surviving section of the lateral edge is straight and the bone thickness is the same as on the opposite side: this indicates that the wound was cleansed. Yet, it cannot be affirmed whether only bone fragments were removed or a "false" trepanation was carried out because no trace of any trepanation tools were observed.

In addition, the fracture of a distal end of the left ulna diaphysis ("parry fracture") suffered by a man from grave $1573 / 154$ was also considered to be an anthropogenic injury. All the other traumatic changes were evaluated as random injuries suffered during everyday life. Similar types of injuries also occur in the present population (Pokorný et al. 2002).

Inflammatory changes were another group of diseases which left traces on the human skeletal remains. Nearly a third were of an odontogenic nature and most likely caused by an infection spreading into the surrounding tissues from a tooth root canal that has been affected by deep caries or that has irritated the attachment apparatus by the hardened dental calculus. They included chronic parodontitis and inflammation inside the maxillary sinus. Traces of parodontitis were detected in four cases $(5.5 \% ; n=73)$. Furthermore, scurvy has always been considered when this type of disease has occurred. However, the absence of ossificated subperiosteal hematomas on the postcranial skeletons excluded vitamin $\mathrm{C}$ deficiency as a factor.

Two cases of maxillary sinusitis, which evidently resulted from a tooth cavity that had been left untreated, were also classified among inflammatory changes of an odontogenic origin. The total frequency of maxillary sinusitis, however, was surprisingly low in the studied skeletal collection $(1.7 \%$; $\mathrm{n}=117$ ). Roberts (2007) observed the occurrence of maxillary sinusitis in seven populations from different periods (the earliest from AD 1500-1600 and the latest from the $18^{\text {th }}$ $19^{\text {th }}$ centuries) which lived in different social-economic conditions. The frequency of occurrence ranged from 17.2 to $51.5 \%$. The researcher primarily focused on air quality in the observed localities because in her view, the spreading of infection from the nasal cavity during the inflammation of the upper respiratory tract is the main cause of this disease. Nevertheless, the extremely low occurrence of maxillary sinusitis in the sample of the population from Prague-Zličín indicates that unpolluted air is not the only influence. The significant damage of the skeletal collection is probably the main factor: as most maxillae found were incomplete - and fragments of bones with pathological changes need not have survived.

Two cases of tuberculosis, representing $1.8 \%(n=113)$ of the group, belonged to the most interesting findings associated with inflammatory diseases. Proceeding from current clinical practice, where bones and joints of about $5 \%$ of people suffering from tuberculosis are affected (Steinbock 1976; Aufderheide, Rodríguez-Martín 1998), this mathematical reflection may be used to estimate the total percentage of tuberculosis. From this point of view, the two skeletons with tuberculosis changes could theoretically correspond to 40 individuals affected by tuberculosis, which represents about $35.5 \%$ of the entire analysed collection $(n=113)$. However, even this method of calculating tuberculosis frequency does not provide an accurate picture of the disease in the studied population because of the poor preservation of the osteological collection. The true occurrence of this feared disease was most likely slightly higher. Thus far, Holloway et al. (2011) have recorded 531 diagnosed paleopathological findings of tuberculosis from 221 localities around the world (dated from BC 7250 to AD 1899). The cases of bone tuberculosis from Prague-Zličín will enrich this vast collection by two more cases during the Migration Period.

In addition to inflammatory changes, our researchers examined for neoplastic diseases. Only benign tumours were detected; however, this fact cannot be interpreted as an absolute absence of malign bone tumours or carcinogen influences because of the fragmentary condition of the skeletons. The sporadic occurrence of cribra orbitalia, frontal internal hyperostosis, and biparietal thinning is most 
likely caused by the fragmentary skeletal remains; therefore, it is very difficult to compare the data with better-preserved collections.

The abnormal connection of the heel and navicular bone (calcaneonavicular coalition) of the woman from grave 530/19 was among the most interesting paleopathological findings of the analysed skeletal collection. The tarsal coalition is an innate genetically-determined disorder which is caused by a malfunction of segmentation and differentiation of the primitive mesenchyme during embryogenesis (Kulik, Clanton 1996). It is an abnormal connection of two or more tarsal bones with connective tissue; most often it is a tissuecartilage synarthrosis, less often a synostosis.

The tarsal coalition may result in a spasm, via the pressing on the fibular muscles, and cause a spastic flat foot or even a rigid flat foot to result in a painful foot, heel valgosity, and limited mobility of the subtalar joint (Dungl et al. 2005).

The total frequency of tarsal coalitions differs from one population to another. Recent clinical research estimates their frequency at 1-2\% (Case, Burnett 2012) while cadaver studies usually record a higher occurrence; for example Rühli et al. (2003) presented the overall prevalence of tarsal coalitions as $13.0 \%$ and of calcaneonavicular coalitions as $7.0 \%$. Case and Burnett (2012) based the cause for these differences to be the examination methods and the character of the analysed sample. Current clinical studies usually determine the prevalence of tarsal coalitions based on radiological examinations of patients suffering from foot pain; therefore only cases of fibular spastic flat foot are being detected while the asymptomatic coalitions remain uncovered (Leonard 1974).

In case of genetically-determined defects, such as tarsal coalitions, the frequency of their occurrence is strongly influenced by family relationships, as evidenced by Leonard (1974). Case and Burnett (2012) recorded geographical differences in the occurrence of types and frequencies of tarsal coalitions. The calcaneonavicular coalition was most frequent in the samples from European populations: the frequency in the Medieval Danish population equalled $2.2 \%$, while South Africans showed only a sporadic occurrence $(0.2 \%)$. The occurrence of tarsal coalitions in most studies was not influenced by sexual dimorphism (e.g. Leonard 1974; Rühli et al. 2003; Case, Burnett 2012) and statistically-important differences between unilateral and bilateral occurrences were not detected (e.g. Kulik, Clanton 1996; Cooperman et al. 2001).

In paleopathological studies, calcaneonavicular coalitions have been researched and described by Angel (1971), Stloukal and Vyhnánek (1976), Dastugue and Metz (1977), Cooperman et al. (2001), Silva (2005; 2010; 2011), Darton (2007), Dinwiddy (2009), Silva and Silva (2010) and Case and Burnett (2012). Most of them were case studies; only Cooperman et al. (2001) and Case and Burnett (2012) recorded the frequency of tarsal coalition in whole skeletal collections. In their studies, the frequency ranged from $0.2 \%$ to $2.2 \%$.

The calcaneus or navicular bones of only 43 individuals could be researched from the skeletal remains of Prague-
Zličín, where the single case of unilateral calcaneonavicular coalition represented a total frequency of $2.3 \%$. The result corresponds fully to the data presented by similar analyses in other European localities.

Comparisions with other skeletal series (Horb-Altheim, Munich-Perlach) bring some difficulties: authors are focused on different skeletal markers and the bone preservation of the Prague-Zličín population is very poor (no skeletal material from almost one half of all individuals). However, some interesting data can be mentioned. Horb-Altheim includes a total of 75 individuals, the collection composed of 26 males, 36 females and 12 adolescents ( 6 boys, 6 girls) and one undetermined infant (Obertová 2008). The MunichPerlach population consists of 32 individuals, 18 females ( 10 certain females, 8 probably females), 11 males ( 8 certain, 3 probably), 3 undetermined individuals; 8 individuals from the total are infants (Zintl, von Heyking 2016).

In the Horb-Altheim population the same patterns in degenerative joint diseases were discovered. The frequency of degenerative changes was also quite high, the most frequently affected areas being the lumbar vertebra and hip joints. The authors recorded significant differences between the right and left elbow being affected (the right elbow was affected more) and also significant differences between male and female hip bones being affected (male hip bones affected more). Traumas were more frequently observed in the HorbAltheim population than at Prague-Zličín. At Horb-Altheim, $42.3 \%$ males and $13.9 \%$ females were affected, whereas at Prague-Zličín only $8.8 \%$ of all individuals were affected. The difference between Horb-Altheim individuals was significant, whereas at Zličín such a difference between sexes could not be observed, due to the state of the bone material (as stated above). At Horb-Altheim, the tibia was the most affected bone $(66.7 \%)$; other inflammatory changes were observed on the skull (cribra orbitalia, porotic hyperostosis). Out of a total sample of 61 skulls at Horb-Altheim, 19 individuals suffered from cribra orbitalia (31.1\%). At Munich-Perlach, 46.4\% (13 out of 28) individuals were affected by cribra orbitalia. This is also quite a big difference from the Zličín population (7.1\%); but, at Zličín, only 28 (out of 113) individuals with preserved orbits were available. Dental enamel hypoplasia was detected in many individuals within all the mentioned localities, with a similar frequency: at Prague-Zličín it was 47.5\% (Jarošová 2016), at Horb-Altheim 55\%, at MunichPerlach $44 \%$ of individuals.

There exist a lot of records of intestinal parasites, both multicellular and unicellular, from archaeological sites; however, they are mostly faecal in origin from cesspits, wells, etc. (Bartošová et al. 2011; Fernandes et al. 2005; Florenzano et al. 2012; Myšková et al. 2014; Rocha da et al. 2006; Yeh et al. 2014). The main problem of this material lies in the fact that, despite the parasites being found, they cannot be directly assigned to a specific host. In the case of coprolites we are able to connect the parasitofauna with one individual; however, the origin of this material is also not always clear. The most reliable connection is the finding of a parasite in human or animal remains. There are records 
of parasites in mummies and other well preserved human remains (Cockburn et al. 1975; David 1997; Oeggl 2009; Seo et al. 2014; Shin et al. 2011; Horne 2002; Sianto et al. 2005; Wei 1973), but for skeletal graves there exist very few records (Dittmar, Teegen 2003; Jaeger et al. 2013; Mitchell et al. 2013).

Despite the high sensitivity methods that are used nowadays, it is not very common to recover parasitic DNA and the parasites themselves in archaeological material. Failure to prove parasites present in the archaeological material does not necessarily mean that the material had not contained parasites, due to the risk of degradation in this material being very high. A lot of factors must combine successfully for there to be preservation of parasitological material in archaeological samples. Factors thought to have an influence on the preservation of parasites and their DNA in samples are mainly age and origin of the samples (graves-skeletal, mummies, cesspits, soil, etc.), handling of material during the excavation on the archaeological site and subsequent storage of samples.

In the case of parasitological grave material we were confronted with many difficulties. The environment (soil composition) in which the remains were found could itself be a problem. The soil was very sandy and permeable and could contribute to degradation. The long period of time for this excavation (nearly 7 years, due to financial reasons) and then the long period of storage could have dried out the samples and DNA persistence been degraded. The lack of intestinal parasites could also be due to general decomposition processes after the death of individuals. Soil processes could also play a role, for example: leaching, lower $\mathrm{pH}$ conditions, and the decomposition of humic acids and of other organic compounds in the dominantly-sandy sediments.

\section{Conclusion}

What can we say about the state of health of the Vinarice people? Signs of the majority of common diseases were found on the analysed skeletal remains. Joint diseases were the most numerous pathological changes detected in the collection. Their frequency and spectre is comparable to the present-day population and gives no evidence of abnormal physical loads on the studied population sample. Most of the detected traumatic changes correspond with random injuries received during normal everyday routine. With one exception, no traces of injuries typical of war periods were discovered on the analysed bones. Likewise, no increase in the total number of metabolic disease manifestations (mainly cribra orbitalia) was found; such increases usually being associated with famines (Steinbock 1976). No sex or age differences in female and male morbidity were found. Unfortunately, we could not perform any statistical evaluation, due to nearly half of all buried individuals being unavailable for examination. It is possible that missing skeletons, predominantly of children, could have changed the overall evaluation results. Such typical signs for the
Migration Period as deformed skulls were also not found. But only five complete skulls were preserved, so artificial deformities were not observable.

It would seem possible to find ancient human hairs, if the grave conditions should be suitable. Such specific conditions, allowing the preservation of organic material and also hairs, were found in two graves from Prague-Zličín. On these hairs we could observe mechanic, chemical and organical damage, but find no signs of ectoparasites.

Highly-sensitive molecular methods seem to be inefficient in dealing with old and inappropriately-stored soil samples. Abiding by the conditions for handling and storing samples will be important for this type of analysis in the future.

The poor state of bone preservation has not allowed the health status of the buried people to be described in detail, but the data obtained has shown some trends. The low proportions of traumas or inflammatory changes may indicate a population enjoying a quite peaceful period and a rich quality diet. This would lead to a robust figure and quite high body stature, but increased caries intensity. As a major problem it seems to be the stress in childhood that caused the common occurrence of enamel hypoplasia. Perhaps these bad living conditions improved once these individuals reached maturity.

Up to the present time, the paleopathological, trichological and parasitological analyses of human skeletal and hair remains from Prague-Zličín stand as a unique, comprehensive study of the health condition of the Vinařice cultural group of Germanic populations from the early stage of the Migration Period ( $5^{\text {th }}$ century) in the Czech Republic.

\section{Acknowledgement}

This project has been funded with the support from the Czech Science Foundation, grant number P405/13-18955S.

\section{References}

APPLEYARD, H. M. 1978: Guide to the Identification of Animal Hairs. Wira, Leeds.

ANGEL, J. L. 1971: The People of Lerna. Analysis of a Prehistoric Aegean Population. Smithsonian Institution Press, Washington, DC.

AUFDERHEIDE, A. C., RODRÍGUEZ-MARTÍN, R. C. 1998: The Cambridge Encyclopedia of Human Paleopathology. Cambridge University Press, Cambridge.

BARTOŠOVÁ, L., DITRICH, O., BENEŠ, J., FROLÍK, J., MUSIL, J. 2011: Paleoparasitological findings in medieval and early modern archaeological deposits from Hradebni Street, Chrudim, Czech Republic. Interdisciplinaria Archaeologica - Natural Sciences in Archaeology II/1/2011, 27-38.

BAUMGARTNER, W., HILL, V. 1993: Sample preparation techniques. Forensic Science International 63, 121-135.

BEŇUŠ, R., MASNICOVÁ, S. 2001: Rekonštrukcia fyzického stressu (s dôrazom na sledovanie osteoartrózy) u historickej bratislavskej populácie. EuroRehab 1, 24-33.

BROTHWELL, D. R. 2005: The Tyrolean Iceman and questions of taphonomy and tissue identification. Journal of Biological Research 80, 215-216.

BUCKHOLT, M. A., LEE, J. H., TZIPORI, S. 2002: Prevalence of Enterocytozoon bieneusi in swine:An 18-month survey at a slaughterhouse 
in Massachusetts. Applied and Environmental Microbiology 68, 2595-2599.

CALLEN, E. O., CAMERON, T. N. 1960: A prehistoric diet as revealed in coprolites. New Scientist 8, 35-39.

CASE, D. T., BURNETT, S. E. 2012: Identification of Tarsal Coalition and Frequency Estimates from Skeletal Samples. International Journal of Osteoarchaeology 22 (6), 667-684.

CHANG, B. S., HONG, W. S., LEE, E., YEO, S. M., BANG, I. S., CHUNG, Y. H., LIM, D. S., MUN, G. H., KIM, J., PARK, S. O., SHIN, D. H. 2005: Ultramicroscopic observations on morphological changes in hair during 25 years of weathering. Forensic Science International 151, 193-200.

COCKBURN, A., BARRACO, R. A., REYMAN, T. A., PECK, W. H. 1975 : Autopsy of an Egyptian mummy. Science 187, 1155-1160.

COOPERMAN, D. R., JANKE, B. E., GILMORE, A., LATIMER, B. M., BRINKER, M. R., THOMSON, G. H. 2001: A Three-Dimentional Study of Calcaneonavicular Tarsal Coalition. Journal of Pediatric Orthopaedics 21, 648-651.

CRUBÉZY, E., GOULET, J., BRUZEK, J., JELÍNEK, J., ROUGÉ, D., LUDES, B. 2002: Epidemiology of osteoarthritis and enthesopathies in a European population dating back 7700 years. Joint Bone Spine 69, 580-588.

DARTON, Y. 2007: Flat foot: The palaeopathological diagnosis. International Journal of Osteoarchaeology 17, 286-298.

DASTUGUE, J., METZ, F. 1977: Bloc calcaneo-naviculaire bilatéral sur un squelette Mérovingien. Journal de Medecine de Caen 12, 137-140.

DAVID, A. R. 1997: Disease in Egyptian mummies: The contribution of new technologies. The Lancet 349, 1760-1763.

DIDIER, E. S., VOSSBRINCK, C. R., BAKER, M. D., ROGERS, L. B., BERTUCCI, D. C., SHADDUCK, J. A. 1995: Identification and characterization of three Encephalitozoon cuniculi strains. Parasitology 111, 411-421.

DINWIDDY, K. J. 2009: A Late Roman Cemetery at Little Keep. Dorchester, Dorset. Wessex Archaelogy. Salisbury.

DITTMAR, K., TEEGEN, W. R. 2003: The presence of Fasciola hepatica (liver-fluke) in humans and cattle from a 4500 year old archeological site in the Saale-Unstrut valley, Germany. Memórias do Instituto Oswaldo Cruz, Rio de Janeiro 98 (Suppl. I), 141-143.

FAEGRI, K., IVERSEN, J. 1989: Textbook of Pollen Analysis. Chichester. DOBISÍKOVÁ, M. 1999: Určování věku. In: Stloukal, M., Dobisíková M., Kuželka, V., Stránská, P., Velemínský, P., Vyhnánek, L., Zvára, K. (Eds.): Antropologie. Př́ručka pro studium kostry. Národní muzeum, Praha, 235-339.

DROBERJAR, E. 2002: Encyklopedie řmské a germánské archeologie $v$ Čechách a na Moravé. Libri, Praha.

DUNGL, P., CHROMIAK, J., KOFRÁNEK, I., KUBEŠ, R., KALOUS, T., MATĚJOVSKÝ, Z., PODŠKUPKA, A., TÓTH, L., ADAMEC, O., FRYDRYCHOVÁ, M., HAJNÝ, P., KASAL, T., KOLMAN, J., KOUTNÝ, Z., MAJERNÍČEK, M., MATĚJÍČEK, M., MATĚJOVSKÝ, Z., VACULÍK, J., VČELÁK, J., ZÁVITKOVSKÝ, P., ZVĚŘINA, E., EHLER, E., CHROUSTOVÁ, D., REJHOLEC, M., ŠTROF, J. ŽIŽKOVÁ, K. (2005): Ortopedie. Grada Publishing, Praha, 618-621.

FAEGRI, K., IVERSEN, J. 1989: Textbook of Pollen Analysis. Chichester.

FERNANDES, A., FERREIRA, L. F., GONÇALVES, M. L. C., BOUCHET, F., KLEIN, C. H., IGUCHI, T., SIANTO, L., ARAÚJO, A. 2005: Intestinal parasite analysis in organic sediments collected from a $16^{\text {th }}$ century Belgian archeological site. Cadernos de Saúde Pública, Rio de Janeiro 21, 329-332.

FIBIGER, L., KNÜSEL, C. J. 2005: Prevalence Rates of Spondylolysis in British Skeletal Populations. International Journal of Osteoarchaeology 15 (3), 164-174.

FLORENZANO, A., MERCURI, A. M., PEDERZOLI, A., TORRI, P., BOSI, G., OLMI, L., RINALDI, R., MAZZANTI, B. 2012: The significance of intestinal parasite remains in pollen samples from Medieval pits in the Piazza Garibaldi of Parma, Emilia Romagna, Northern Italy. Geoarchaeology: An International Journal 27, 34-47.

FREDERICKSON, B. E., BAKER, D., MC-HOLICK, W. J., JUAN, H. A., LUBICKY, J. P. 1984: The natural history of spondylolysis and spondylolisthesis. Journal of Bone and Joint Surgery, American Volume 66 (5), 699-707.

HENGEN, O. P. 1971: Cribra orbitalia. Pathogenesis and probable aetiology. Homo 22 (2), 57-76.

von HEYKING, K., ZINTL, S. 2016: The early-merovingian cemetery in München-Perlach (Bavaria) - analysing skeletal morphology, health and disease and strontium isotope ratios. Interdisciplinaria Archaeologica -
Natural Sciences in Archaeology VII/1/2016, 111-121.

HOLLOWAY, K. I., HENNEBERG, R. J., DE BARTOS LOPES, M., HENNEBERG, M. 2011: Evolution of human tuberculosis: A systematic review and meta-analysis of paleopathological evidence. Homo 62, 402 458.

HORÁČKOVÁ, L., STROUHAL, E., VARGOVÁ, L. 2004: Základy paleopatologie. In: Malina, J. (Ed.): Panoráma biologické a sociokulturni antropologie 15, Nadace Universitas Masarykiana, Edice Scientia, Brno.

HORÁČKOVÁ, L. 2004: Vrozené anomálie a dysplázie. In: Horáčková, L., Strouhal, E., Vargová, L.: Základy paleopatologie. In: Malina, J. (Ed.): Panoráma biologické a sociokulturní antropologie 15, Nadace Universitas Masarykiana, Edice Scientia, Brno, 37-53

HORNE, P. D. J. 2002: First evidence of enterobiasis in ancient Egypt. Journal of Parasitology 88, 1019-1021.

CHAPMAN, V. (2007): The Anteater Nose Sign. Radiology 245 (2), 604-605.

JAEGER, L. H., TAGLiORETTI, V., FUGASSA, M. H., DiAS, O., NETOC, J., IÑIGUEZ, A. M. 2013: Paleoparasitological results from XVIII century human remains from Rio de Janeiro, Brazil. Acta Tropica $125,282-286$.

JAROŠOVÁ, I. 2016: An Investigation of Dental Health in Migration Period: A Case Study from the Prague-Zličín, Czech Republic. Interdisciplinaria Archaeologica - Natural Sciences in Archaeology VII/1/2016, 33-54.

JIANG, J., ALDERISIO, K. A., XIAO L. 2005: Distribution of Cryptosporidium genotypes in storm event water samples from three watersheds in New York. Applied and Environmental Microbiology 71, 4446-4454.

JURMAIN, R. D. 1977: Stress and etiology of osteoarthritis. American Journal of Physical Anthropology 46 (2), 353-365.

JURMAIN, R. D. 1991: Degenerative changes in peripheral joints as indicator of mechanical stress: Opportunities and limitations. International Journal of Osteoarchaeology 1 (3-4), 247-252.

KALICHMAN, L., KIM, D. H., LI, L., GUERMAZI, A., BERKIN, V., HUNTER, D. J. 2009: Spondylolysis and spondylolisthesis: prevalence and association with low back pain in the adult community-based population. Spine 34 (2), 199-205.

KALOVÁ, K. 2012: Paleopatologické hodnocení obyvatel Pohanska u Břeclavi. Doctoral thesis. Deposited: Ústav antropologie, Přírodovědecká fakulta, Masarykova univerzita, Brno.

KATZWINKEL-WLADARSCH, S., LIEB, M., HELSE, W., LÖSCHER, T., RINDER, H. 1996: Direct amplification and species determination of microsporidian DNA from stool specimens. Tropical Medicine and International Health 1, 373-378.

KLOZAR, J., ASTL, J., HUDEČKOVÁ, A., JABLONECKÝ, P., KLIMÁK, P., KLUH, J., KRAUS, J., KUČERA, Z., KUČEROVÁ, D., KUCHYNKOVÁ, Z., LAŠTŮVKA, P., LISCHKEOVÁ, B., LUKÁS̆, J., MRZENA, L., SKŘIVAN, J., SLAVÍČEK, A., ŠMILAUER, T., TAUDY, M., VRABEC, P., ZVĚŘINA, E. 2005: Speciální otorinolaryngologie. Galén, 1. vydání. Karolinum, Praha.

KUBÁČEK, V., BAŘINKA, L., JAKUBÍK, J., KRENAR, J., MARTINOVÁ, M., MICHÁLEK, V., NĚMEC, A., POSPÍŠILOVÁ, J., RIEBELOVÁ, V., SAMOHÝL, J., VÁLKA, J., KOPŘIVOVÁ, M. 1982: Chirurgie ruky. Universita J. E. Purkyně v Brně, Brno.

KUBÁLEK, P., MALÁ, P. 2011: Podoba ženy ze Zličína. Základní antropologické zpracování ostatků z germánského hrobu č. 78 v PrazeZličíně. In: Droberjar, E. (Ed.): Archeologie barbarů 2010. Hroby a pohřebiště Germánů mezi Labem a Dunajem. Sborník příspěvků z VI. Protohistorické konference Hradec Králové, 6.-9. září 2010, 239-247.

KULIK, S. A., CLANTON, T. O. 1996: Tarsal Coalition. Foot Ankle International 17 (5), 286-296.

LEONARD, M. A. 1974: The Inheritance of Tarsal Coalition and its Relationship to Spastic Flat Foot. Journal of Bone and Joint Surgery 56 (3), 520-526.

LEWIS, J. E. 2008: Identifying sword marks on bone: criteria for distinguishing between cut marks made by different classes of bladed weapons. Journal of Archaeological Science 35, 2001-2008.

LOREILlE, O., ROUMAT, E., VERNEAU, O., BOUCHET, F., HÄNNI, C. 2001: Ancient DNA from Ascaris: Extraction amplification and sequences from eggs collected in coprolites. International Journal for Parasitology 31, 1101-1106.

MITCHELL, P., YEH, H., APPLEBY, J., BUCKLEY, R. 2013: The intestinal parasites of King Richard III. The Lancet 382, 888. 
MØLLER-CHRISTENSEN, V., SANDISON, A. T. 1963: Usura orbitae (cribra orbitalia) in the collection of crania in the Anatomy Department of the University of Glasgow. Pathological Microbiology (Basel) 26, 175-183.

MOSELEY, J. E. 1963: Bone changes in hematologic disorders: Implications for Paleopathology. In: Jarcho, S. (Ed.): Human Palaeopathology. New Haven and London, Yale University Press, 121-130.

MYŠKOVÁ, E., DITRICH, O., SAK, B., KVÁČ, M., CYMBALAK, T. 2014: Detection of ancient DNA of Encephalitozoon intestinalis (Microsporidia) in archaeological material. The Journal of Parasitology 100, 356-359.

NATHAN, H. 1959: Spondylolysis. Journal of Bone and Joint Surgery 41 A (2), 303-317.

NIKITA, E., MATTINGLY, D., LAHR, M. M. 2013: Methodological considerations in the statistical analysis of degenerative joint and disc disease. International Journal of Paleopathology 3, 105-112.

OBERTOVÁ, Z. 2008: The Early Medieval Alamannic Population at HorbAltheim (450-510 A.D.). In: Conrad, N. J., Haidle, M. N., Uerpmann, H.-P., Wahl, J. (Eds.): BioArcheologica. Band 4. Verlag Marie Leidorf $\mathrm{GmbH}$, Rahden/Westf.

OEGGL, K. 2009: The significance of the Tyrolean Iceman for the archaeobotany of Central Europe. Vegetation History and Archaeobotany $18,1-11$.

OGLE R, R., FOX, M. J., 1999: Atlas of Human Hair - microscopic characteristics. CRC Press LLC.

OH, C. S., SEO, M., CHAI, J. Y., LEE, S. J., KIM, M. J., PARK, J. B., SHIN, D. H. 2010: Amplification and sequencing of Trichuris trichiura ancient DNA extracted from archaeological sediments. Journal of Archaeological Science 37, 1269-1273.

ORTNER, D. J. 2003: Identification of Pathological Conditions in Human Skeletal Remains. Academic Press, London, second edition.

ORTNER, D. J., PUTSCHAR, W. 1985: Identification of Paleopathological Conditions in Human Skeletal Remains. Smithsonian Contributions to Antropology, 28. Washington, DC,

Smithsonian Institution Press.

POKORNÝ, V., ČIŽMÁŘ, I., HAVRÁNEK, P., KUČERA, J., MICHEK, J., SVOBODA, P., VESELÝ, J., VIŠNA, P., VRASTYÁK, J., WENDSCHE, P. 2002: Traumatologie. Triton, Praha.

REJHOLEC, V. 1982: Osteoartrosa. Artrosa. Osteoartritis. Degenerativni kloubní nemoc (715). In: Štork A. (Ed.): Lékařské repetitorium. Avicenum, zdravotnické nakladatelství, svazek II, čtvrté přepracované vydání, Praha, 1246-1250.

ROBERTS, CH. A. 2007: A Bioarcheological Study of Maxillary Sinusitis. American Journal of Physical Anthropology 133, 792-807.

ROCHA da, G. Ch., HARTER-LAILHEUGUE, S., BAILlY Le, M., ARAÚJO, A., FERREIRA, L. F., SERRA-FREIRE da, N. M., BOUCHET, F. 2006: Paleoparasitological remains revealed by seven historic contexts from „Place d'Armes“, Namur, Belgium. Memórias do Instituto Oswaldo Cruz, Rio de Janeiro 101(Suppl. II), 43-52.

RÜHLI, F. J., SALOMON, L. B., HENNEBERG, M. 2003: High Prevalence of Tarsal Coalitions and Tarsal Joint Variants in a Recent Cadaver Sample and Its Possible Significance. Clinical Anatomy 16, 411-415.

SEO, M., ARAÚJO, A., REINHARD, K., CHAI, J. Y., SHIN, D. H. 2014 Paleoparasitological studies on mummies of the Joseon Dynasty, Korea. Korean Journal of Parasitology 52, 235-242.

SHIN, D. H., OH, Ch. S., CHAI, J-Y., LEE, H-J., SEO, M. 2011: Enterobius vermicularis eggs discovered in coprolites from a medieval Korean mummy. Korean Journal of Parasitology 49, 323-326.

SIANTO, L., REINHARD, K. J., CHAME, M., CHAVES, S., MENDONÇA, S., GONÇALVES, M. L. C., FERNANDES, A., FERREIRA, L. F., ARAÚJO, A. 2005: The finding of Echinostoma (Trematoda: Digenea) and hookworm eggs in coprolites collected from a Brazilian mummified body dated 600-1,200 years before present. The Journal of Parasitology 91, 972-975.

SILVA, A. M. 2005: Non-osseous Calcaneonavicular Coalition in the Portuguese Prehistoric Population: Report of Two Cases. International Journal of Paleopathology 15, 449-453.

SILVA, A. M. 2011: Foot anomalies in the Late Neolithic / Chalcolithic population exhumed from the Rock Cut Cave of Sao Paulo 2 (Almada, Portugal). International Journal of Paleopathology 21 (4), 420-427.

SILVA, A. M., SILVA, A. L. 2010: Unilateral non-osseous calcaneonavicular coalition. Report of Portuguese archeological case. Anthropological
Science 118, 61-64

SMRČKA, V., KUŽELKA, V., POVÝŠIL, C. 2009: Atlas chorob na kostnich preparátech. Horni a dolni končetiny. Academia, Praha.

STEINBOCK, R. T. 1976: Paleopathological Diagnosis and Interpretation. Charles C. Thomas Publisher, Springfield, Illinois.

STLOUKAL, M., VYHNÁNEK, L. 1976: Slované z velkomoravských Mikulčic. Academia, Praha.

STROUHAL, E. 2004: Choroby zubů a alveolů. In: Horáčková, L., Strouhal, E., Vargová, L.: Základy paleopatologie. In: Malina, J. (Ed.): Panoráma biologické a sociokulturní antropologie 15, Brno, Nadace Universitas Masarykiana, Edice Scientia, Brno, 177-188.

SULAIMAN, I. M., FAYER, R., BERN, C., GILMAN, R. H., TROUT, J. M., SCHANTZ, P. M., DAS, P., LAL, A. A., XIAO, L. 2003: Triophosphate isomerase gene characterization and potential zoonotic transmission of Giardia duodenalis. Emerging Infectious Diseases 9, 1444-1452.

SVOBODA, B. 1965: Čechy v době stěhování národů. Academia, Praha.

TEERINK, B. J. 2003: Hair of West-European Mammals. Cambridge University Press, Cambridge.

TESAŘ, J. 1968: Soudni lékařství. Státní zdravotnické nakladatelství, Praha, 228-229.

TSIRIKOS, A. I., GARRIDO, E. G. 2010: Spondylolysis and spondylolisthesis in children and adolescents. Journal of Bone and Joint Surgery (Br) 92 B (6), 751-759.

VARGOVÁ, L., HORÁČKOVÁ, L. 2005: Degenerative joint changes found in skeletal remains from a modern period cemetery in Antonínská street in Brno. Slovenská antropológia 8 (2), 142-147.

VARGOVÁ, L., HORÁKOVÁ, M., HORÁČKOVÁ, L. (2014): Kloubní a traumatické změny na kosterních pozůstatcích $\mathrm{z}$ doby stěhování národů z pohřebiště v Praze-Zličíně. Slovenská antropológia 17/1, 120-123.

VARGOVÁ, L., HORÁČKOVÁ, L., VYMAZALOVÁ, K., SVOBODA, J. 2013: Palaeopathological Analysis of Skeletons from the $16^{\text {th }}$ and $17^{\text {th }}$ Centuries (Veselí nad Moravou, Czech Republic). Anthropologie 51/3, 397-408.

VÁVRA, J. 2016: Interdisciplinary Research of the Migration Period Cemetery at Prague-Zličín, Czech Republic, Editorial IANSA 1/2016. Interdisciplinaria Archaeologica - Natural Sciences in Archaeology VII/1/2016, 3-10.

VÁVRA, J., JIŘÍK, J., KUCHAŘÍK, M., KUBÁLEK, P. 2009: Výzkum pohřebiště z doby stěhování národů v Praze-Zličíně v letech 2005-2008. Archaeologica Pragensia 19, 211-232.

VÁVRA, J., JIŘÍK, J., KUCHAŘÍK, M., JAROŠOVÁ, I., VÍŠKOVÁ, M., KUBÁLEK, P. 2012: The Migration Period burial site in Prague-Zličín, Czech Republic. Preliminary report. Zeitschrift für Archäologie des Mittelalters 40, Universität Freiburg, Bonn, 1-25.

VÍŠKOVÁ, M., JAROŠOVÁ, I., JIŘIIK, J., VÁVRA, J., KUCHAŘÍK, M. 2012: Populace $\mathrm{z}$ doby stěhování národů z pohřebiště v Praze-Zličíně z pohledu fyzické antropologie. Acta Musei Nationalis Pragae, Series A, Historia 66 (3-4), 61-70.

VYHNÁNEK, L., BOHUTOVÁ, J., BELŠÁN, T., DANEŠ, J., FENDRYCH, P., HOŘÁK, J., HOŘEJŠÍ, J., CHMEL, J., KŘIVÁNEK, J., ORT, J., TŮMA, S. 1998: Radiodiagnostika. Kapitoly z klinické praxe. Grada Publishing, Praha, 42.

WALDRON, H. A. 1991: Prevalence and distribution of osteoarthritis in a population from Georgian and early Victorian London. Annals of the Rheumatic Diseases 50, 301-307.

WEI, O. 1973: Internal organs of a 2100-year-old female corpse. The Lancet 2, 1198.

WEISS, E., JURMAIN, R. D. 2007: Osteoarthritis Revisited: A Contemporary Review of Aetiology. International Journal of Osteoarchaeology. 17, 437-450.

WILTSE, L. L., WIDELL, E. H., JACKSON, D. W. 1975: Fatigue fracture. The basic lesion in isthmic spondylolisthesis. Journal of Bone and Joint Surgery 57 A (1), 280-288.

WOO, E. J., SCIULLI, P. W. 2013: Degenerative Joint Disease and Social Status in the Terminal Late Archaic Period (1000-500 B. C.) of Ohio. International Journal of Osteoarchaeology 23, 529-544.

YEH, H-Y., PLUSKOWSKI, A., KALEJS, U., MITCHELL, P. D. 2014 : Intestinal parasites in a mid- $14^{\text {th }}$ century latrine from Riga, Latvia: fish tapeworm and the consumption of uncooked fish in the medieval eastern Baltic region. Journal of Archaeological Science 49, 83-89.

ŽIŽKA, J. 1994: Diagnostika syndromů a malformací. Galén, Praha. 